\title{
Finnish records on the genus Inocybe (Agaricales). Three new species and I. grammata
}

\author{
JUKKA VAURAS
}

\begin{abstract}
VAURAS, J. 1997: Finnish records on the genus Inocybe (Agaricales). Three new species and I. grammata. Karstenia 37:35-56. Helsinki. ISSN 0453-3402

Two new species of Inocybe (Fr.) Fr., sect. Marginatae Kühner, are described from Finland, viz. I. argenteolutea Vauras and I. pargasensis Vauras, and I. decemgibbosa (Kühner) Vauras, comb. nov., is reported for the first time from the Nordic countries. $I$. grammata Quél. is a rather uncommon species in the study area, occurring from the temperate to the arctic zone. The distribution of these four species in Fennoscandia and adjacent areas is mapped, and their ecology and relationships are discussed. It is proposed that I. glabrodisca P.D. Orton should be classified as a member of section Cortinatae Kühner \& Boursier.
\end{abstract}

Key words: Agaricales, Basidiomycetes, Fennoscandia, Inocybe argenteolutea, Inocybe decemgibbosa, Inocybe glabrodisca, Inocybe grammata, Inocybe pargasensis, taxonomy

Jukka Vauras, Biological Collections, Department of Biology, Åbo Akademi University, FIN-20500 Turku, Finland

\section{Introduction}

Comprehensive treatments of the genus Inocybe in Central Europe were recently published by Kuyper (1986) and Stangl (1989), and a key to 90 species of Inocybe in Sweden was published by Stridvall \& Jacobsson (1989). However, the species of Inocybe in hemiboreal to arctic zones are still insufficiently explored, as indicated, for example, by the many new species recently described from these zones, such as Inocybe mytiliodora and I. urceolicystis (Stangl \& Vauras 1988), I. rivularis (Jacobsson \& Vauras 1990), I. mammifera and I. teraturgus (Moser 1992), I. diabolica (Vauras 1994) and I. hirculus (Vauras 1995).

\section{Material and methods}

During field work in Finland I found two species of Inocybe, which are described here as new species. As they and I. glabrodisca ss. auct. have some features in common with I. grammata Quél., I checked all available material of $I$. grammata from the following herbaria: C, G, GB, H, JYV, KUO, LD, M, PC, O, OULU, S, TAA,
TUR, TURA, UPS, WBS, and the private herbarium of Leif and Anita Stridvall. Further, the bulk of the material filed as Inocybe sp. was checked from BG, H, KUO, O, OULU, TAA, TUR, TURA and UPS. The herbarium abbreviations are according to Holmgren et al. (1990). Herbarium Stridvall is abbreviated in this paper as Herb. LAS.

Microscopical characters were studied with a Leitz Laborlux D. The drawings were made with the Leitz drawing tube under an oil-immersion objective. All measurements and drawings are based on dried material mounted in $10 \% \mathrm{NH} 4 \mathrm{OH}$. The spores were measured including the nodules, the cystidia lengths excluding the crystals, and the basidia lengths excluding the sterigmata. Values within $5 \%$ of each end of the range of spores and pleurocystidia are given in parentheses. The mean values are underlined. The abbreviation $Q$ is the ratio spore length to spore width. The colours of fresh specimens were compared with reference colours in Cailleux (1981) or Küppers (1981). The macroscopical descriptions are based on material from Finland. The specimens from which the microscopical measurements were taken are marked with an asterisk in the list of examined specimens. Soil samples were collected from the humus layer to a depth of $10 \mathrm{~cm}$ very close to the location of fruit bodies and analysed by Soil Analysis Service Ltd. (Finland). 


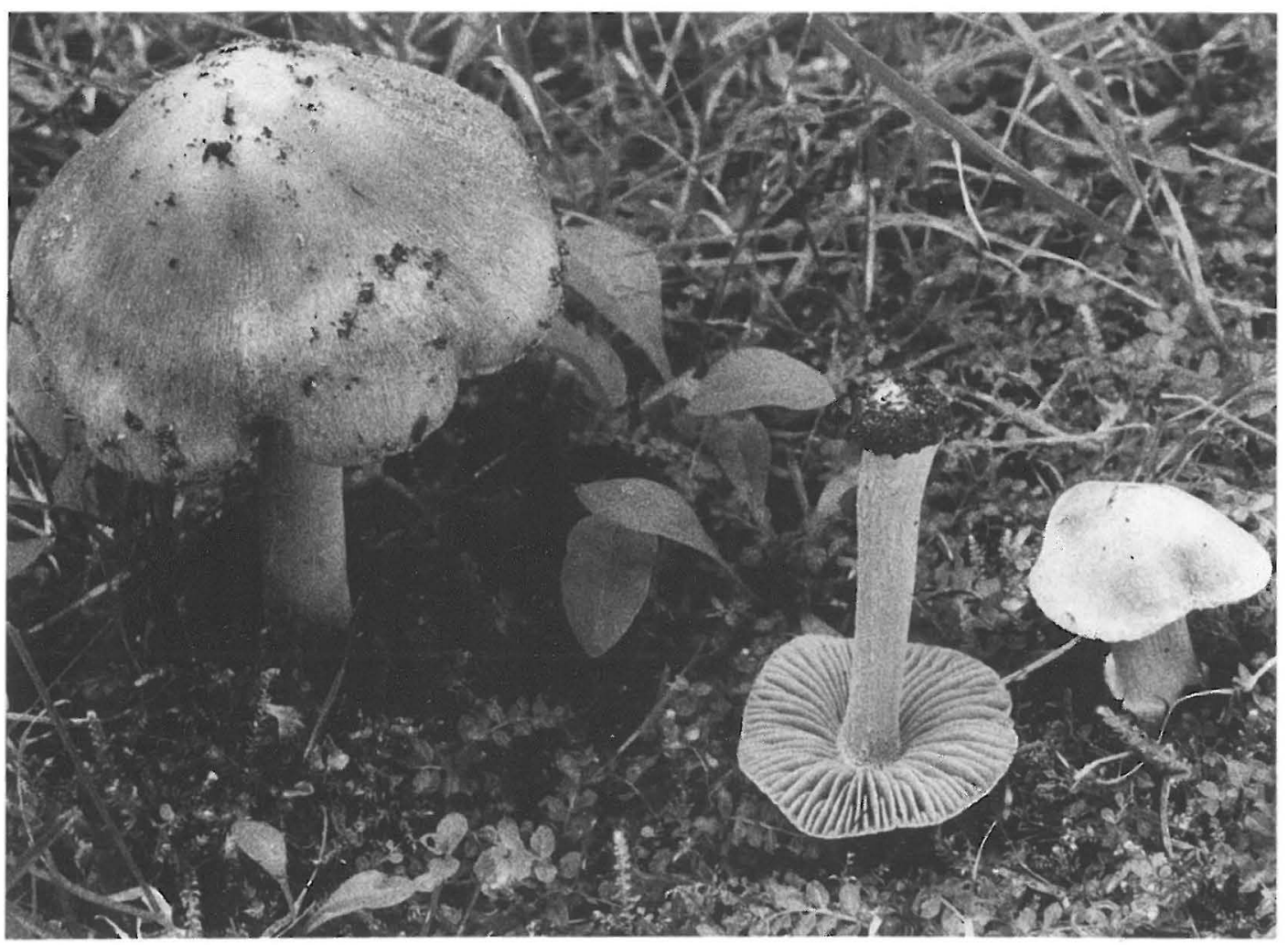

Fig. 1. Fruit bodies of Inocybe grammata, $X$ approx. 1.4, photographed in situ in an old cemetery park, Finland, Etelä-Savo, Mikkeli, 20.VIII.1987 Vauras 2820F (C, TUR, TURA). Photographs Jukka Vauras.

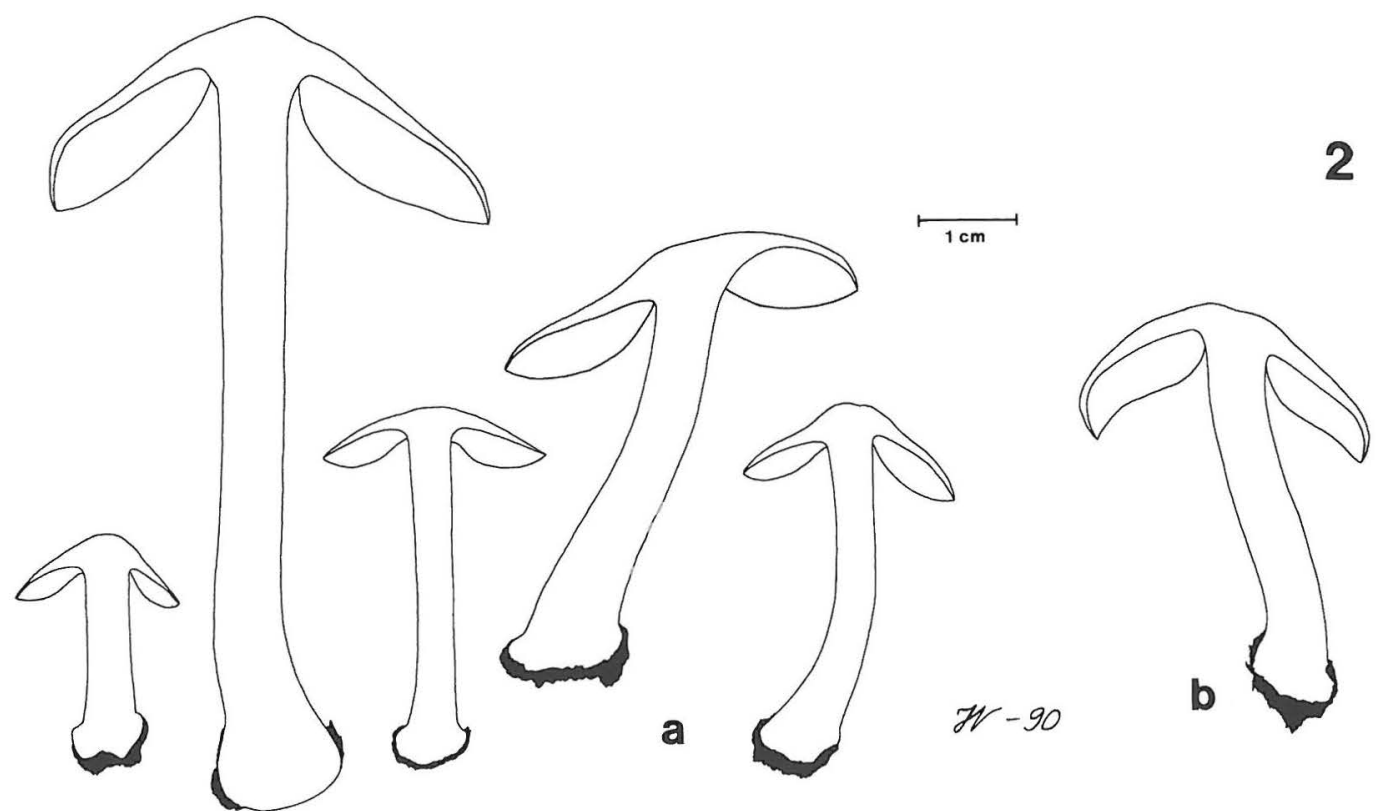

Fig. 2. Fruit bodies of Inocybe grammata, $\times 1$. - a) From Vauras $2820 F$, b) Vauras 2641. 

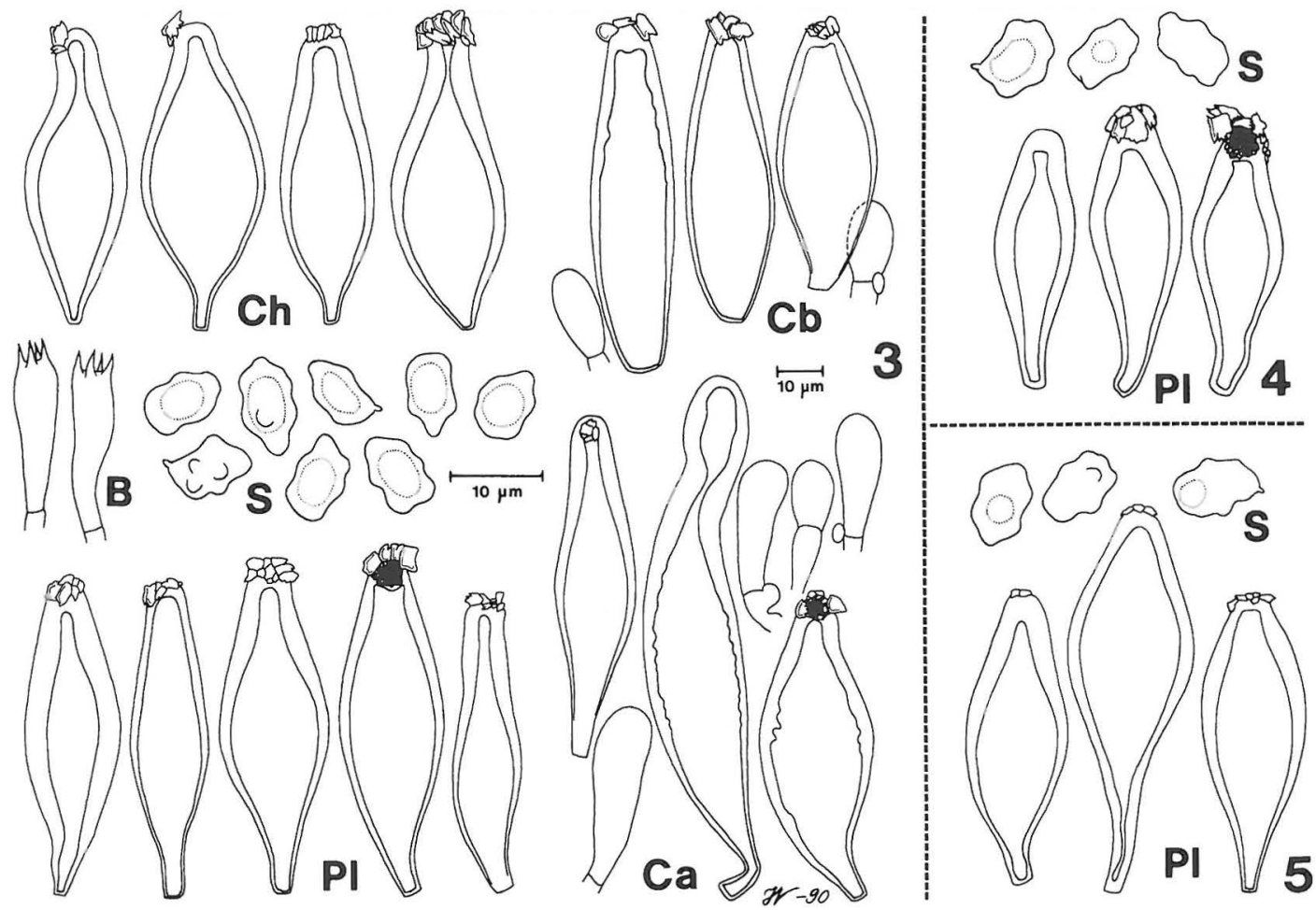

Figs. 3-5. Microscopical characters of Inocybe grammata. - 3: From Vauras 2820F. - 4: From holotype of Inocybe albodisca (NYS). - 5: From Vauras 661F. - Symbols in Figs. 3-5, 10, 15 and 19-21: B = basidia, Ca = caulocystidia and paracaulocystidia at apex of stipe, $\mathrm{Cb}=$ caulocystidia and cauloparacystidia at base of stipe, $\mathrm{Ch}=$ cheilocystidia and paracystidia, $\mathrm{Pl}=$ pleurocystidia, $\mathrm{S}=$ spores. Scales: spores $\times 1000$, others $\times 500$.

Inocybe grammata Quél. - Figs. 1-6, 23

Inocybe grammata Quél., Bull. Soc. Amis Sci. Nat. Rouen, Sér. 2, 15:12. 1879. - Lectotype: Plate 2, Fig. 8 in Quélet, Bull. Soc. Amis Sci. Nat. Rouen, Sér. 2, 15. 1879 (selected here).

Inocybe albodisca Peck, Ann. Rep. New York State Botanist 1897:290. 1898. - Lectotype: U.S.A., New York, Essex County, North Elba, under spruce and balsam fir trees, VIII. C.H. Peck * (NYS; examined; selected here). The type is named as a lectotype because it is not unambiguously the only specimen collected by Peck in North Elba before 1897 (Art. 9.1.).

Inocybe putilla var. semiorbicularis Velen., České Houby: 365. 1920. - Holotype: Czech Republic, Roblín, VII.1916 J. Velenovský (PRC, bottle 124; not examined; Kuyper 1985:396).

Inocybe rostrata Velen., České Houby: 367. 1920. Lectotype: Czech Republic, Revnice, 1916 Kavina (PRC, bottle 284; not examined; selected by Kuyper 1985:397).

Inocybe hiulca (Fr.) Gill. sensu Schulzer \& Kalchbrenner in Icones Sel. Hymenomyc. Hung. 2, Pl. 20 (pro parte). 1877; sensu Bresadola in Fungi Tridentini 2:15. 1892.

Excluded. - Inocybe grammata sensu Heim in Genre Inocybe: 313 and Pl. 24, Fig. 1. 1931 (= Inocybe sp.). - I. grammata sensu Phillips in Mushrooms of North America: 184-185. 1991 (= I. umbratica Quél.?).

Selected illustrations. - Schulzer \& Kalchbrenner, Icones Sel. Hymenomyc. Hung. 2: Pl. 20, Fig. 2. 1877 (as I. hiulca, white fruit body to be excluded). - Bresadola, Iconogr. Mycol. 16: P1. 762.1930 (as I. hiulca). - Lange, Flora Agar. Dan. 3: Pl. 116, Fig. D. 1938. - Stangl, Z. Mykol. 45. 1979. - Phillips, Mushrooms and other fungi of Great Britain and Europe: 153. 1981. - Leisner \& Kalamees, Eesti narmasnutid: P1. 30. 1987. - Stangl, Hoppea 46: Pl. 35, Fig. 2. 1989. - MoënneLoccoz et al., Fungorum Rariorum Icones Coloratae 19: P1. 151. 1990 (as I. grammata and I. albodisca). Phillips, Mushrooms of North America: 184. 1991 (as I. albodisca). - Moser \& Jülich, Farbatlas der Basidiomyceten 13: Inocybe 33. 1995 (as I. margaritispora). 


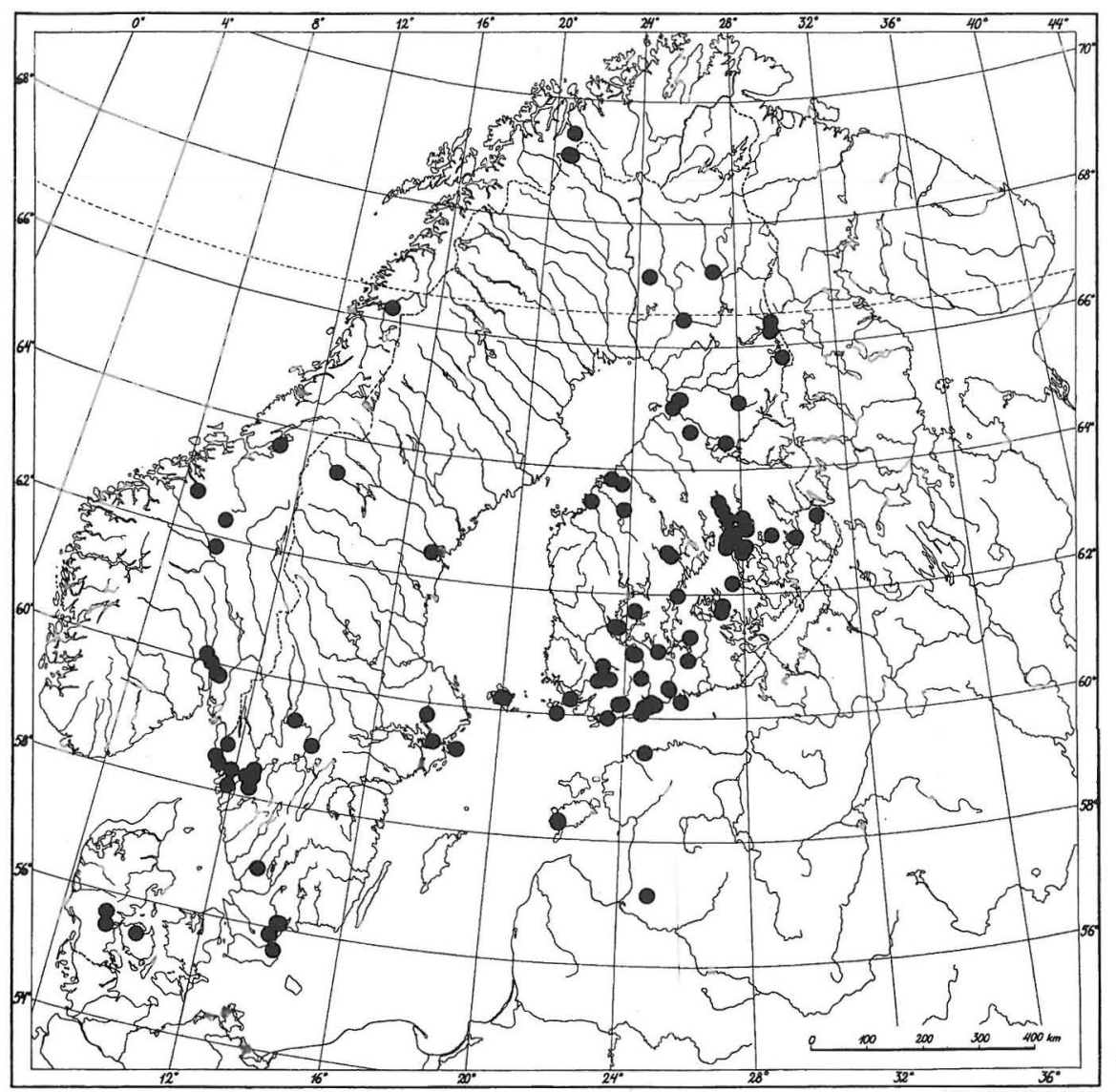

Fig. 6. Distribution of Inocybe grammata in the Nordic and the Baltic countries according to the specimens examined.

Pileus $1.5-4.5 \mathrm{~cm}$ in diam, $8-25 \mathrm{~mm}$ high, obtusely conical when young, later convex, without umbo or broadly umbonate, infrequently slightly depressed, margin often deflexed and undate; surface smooth around disc, at margin felty-fibrillose and rimulose, rarely squamulose, slightly breaking up with age; first silvery grey with bluish tinge (Cailleux 71L, 73K) with pale reddish-yellow (70L, 71L) disc, later disc pale yellowish $(45 \mathrm{~L}, 69 \mathrm{M})$, pale brown $(65 \mathrm{~L}, 75 \mathrm{~L})$, towards margin red-brown $(35 \mathrm{~N}, 53 \mathrm{~N})$, incarnatevinaceous, grey-red $(49 \mathrm{M})$, margin pale greybrown (50L); velipellis conspicuous, sometimes as velar patches (like Inocybe maculata), in mature stages persistent often at margin.

Lamellae up to $7 \mathrm{~mm}$ broad, moderately crowded, often ventricose, narrowly adnate, when young pale grey to brown-grey $(70 \mathrm{M}-\mathrm{N})$, later pale olivaceous brown to brown (49P); edge fibriate, pale.
Stipe 2-8 cm long, 3.5-8 $\mathrm{mm}$ wide, equal to somewhat clavate, with large, often emarginate, up to $13 \mathrm{~mm}$ wide bulb, solid, red (55M), pale red (47L, 49L), pale yellow-red (69M, 67L), pale brown with a pink tinge; white-pruinose all over, longitudinally striate.

\section{Cortina not seen.}

Context in pileus white to whitish, under pileipellis pale brown, in stipe red-tinged, in bulb white. Smell indistinctly spermatic, disagreeable (difficult to describe, somewhat reminiscent of smell of Inocybe oblectabilis).

Spores $(7.0-) 7.5-\underline{8.5}-10.0(-11.5) \times 5.0-\underline{5.6}-$ $6.5(-7.0) \mu \mathrm{m}$, total range of mean values 7.8-9.3 $\times 5.0-5.9 \mu \mathrm{m}, \mathrm{Q}=(1.2-) 1.35-1.50-1.7(-1.9)$, total range of mean $\mathrm{Q}$ values $=1.37-1.59,(680$ spores from 33 collections); subangular, with mainly obscure nodules. Basidia 24-40 $\times 7-11$ $\mu \mathrm{m}$, clavate, 4-spored. 
Pleurocystidia (35-)48- $\underline{60-75(-84) \times(11-)}$ $12-\underline{18}-24(-28) \mu \mathrm{m}(\mathrm{n}=217$, from 33 collections), ventricose, a minority clavate, mostly crystalliferous, base mostly with a downward-tapering pedicel, wall pale yellow to yellow, up to $5 \mu \mathrm{m}$ thick, mostly extending to base of pedicel; frequent. Cheilocystidia 48-74 × 15-26(-29) $\mu \mathrm{m}$, rather frequent. Paracystidia clavate, thinwalled, colourless, scarce.

Caulocystidia occurring down to base of stipe, up to $120 \mu \mathrm{m}$ long, mostly similar to pleurocystidia, but inner line of the wall often unevenly undate. Cauloparacystidia numerous, thin-walled.

\section{Distribution, ecology and phenology}

In Finland Inocybe grammata occurs mostly on mossy lawns in established parks, in pastured forests, beside forest paths and at margins of sandy roads. Occasionally it has been found in other habitats, such as on moist brooksides. The species grows mostly in association with Betula and Picea abies, more rarely with Pinus sylvestris. In southern Sweden and southern Germany it has also been collected in Fagus forests. Favre
(1960) recorded it with Pinus mugo in subalpine zone in Switzerland.

I. grammata clearly favours rich, bare soils. It has often been found in calcareous areas, e.g. near abandoned limestone quarries. However, it does not seem to be among the species frequently found near limestone processing plants, in areas receiving lime dust fall-out. Rather it appears to favour fine sandy soils with humus and mull, though it has also been found on turf soils. The range of $\mathrm{pH}$-values of the soil samples analysed was 4.4-6.0-7.3 (for additional soil characteristics see Table 1).

I. grammata is widely distributed in the Nordic countries, from temperate to arctic zone, but it is rather uncommon in Finland. Many collections have been made in Helsinki and Kuopio, however, where it grows both in parks and in herb-rich forests. The species seems to be absent in some parts of Finland. For example, I have never seen it in my home city of Turku. Nor has it been collected from the province Inarin Lappi in Lapland, an area well represented in the fungi material deposited in TUR. The absence of recordings of $I$. grammata from major parts of western and eastern Finland, as well as from

Table 1. Surface soil characteristics in some, mostly Finnish, localities of Inocybe grammata (1-10), I. argenteolutea (11), I. pargasensis (12-13) and I. decemgibbosa (14). Localities: 1) Ahvenanmaa: Sund, Högbolstad, 31.VII.1991. 2) Varsinais-Suomi (V): Koski Tl., Hongisto, 2.IX.1991. 3) V: Lohja, Tytyri, 22.VII.1990. 4) V: Nauvo, Mälhamn, 6.IX.1993. 5) Etelä-Häme (EH): Hämeenlinna, Ahvenisto, 2.IX.1990. 6) EH: Tampere, Kalevankangas, 14.VIII.1988. 7) EH: Ypäjä, Varsanoja, 17.IX.1990. 8) Pohjois-Savo: Kuopio, Puijo, 11.VIII.1992. 9) Keski-Pohjanmaa: Kokkola, 25.VIII.1990. 10) Estonia. Saaremaa: Viidu, 13.IX.1993. 11) Enontekiön Lappi: Enontekiö, Kilpisjärvi (type site), 11.VIII.1990. 12) V: Parainen, Malmnäs (type site), 12.IX.1988. 13) V: Parainen, Malmnäs, 170 m from the type site, 12.IX.1988. 14) V: Lohja municipality, Kirkonkylä, 28.VI.1994.

\begin{tabular}{|c|c|c|c|c|c|}
\hline Growing site & $\mathrm{pH}$ & $\mathrm{Ca} \mathrm{mg} / \mathrm{l}$ & $\mathrm{K} \mathrm{mg} / 1$ & $\mathrm{Mg} \mathrm{mg/1}$ & P mg/l \\
\hline 1 & 5.5 & 350 & $<20$ & 40 & 1 \\
\hline 2 & 6.2 & 1250 & 25 & 115 & 12 \\
\hline 3 & 7.3 & 3800 & 230 & 200 & 11 \\
\hline 4 & 6.2 & 4360 & 151 & 503 & 19 \\
\hline 5 & 4.4 & 100 & 60 & 45 & 56 \\
\hline 6 & 6.2 & 1600 & 245 & 115 & 29 \\
\hline 7 & 6.6 & - & - & - & - \\
\hline 8 & 5.4 & 1250 & 70 & 265 & 2 \\
\hline 9 & 5.9 & 3300 & 100 & 325 & 49 \\
\hline 10 & 6.6 & 1830 & 57 & 105 & 3 \\
\hline 11 & 5.5 & - & - & - & - \\
\hline 12 & 7.7 & - & - & - & - \\
\hline 13 & 7.6 & $>40000$ & 135 & 390 & 7 \\
\hline 14 & 7.3 & 10900 & 214 & 153 & 24 \\
\hline
\end{tabular}


most of Sweden and southwestern Norway (Fig. 6), could, however, be due to the inactivity of fungus collectors. It is clearly not rare in southwestern Sweden. In the mountains of Scandinavia it grows in mountain birch (Betula pubescens subsp. czerepanovii) forests. In the Kilpisjärvi area, on the fjeld Pikku-Malla, it has once been recorded above the timberline, close to a snow-bed.

I. grammata appears to have a wide holarctic distribution. In Europe it has been classified as rare in the Netherlands (Arnolds 1984) and East Germany (Gröger 1986), though Alessio (1980) states that it is a common species. A map of its distribution in West Germany is given in Krieglsteiner (1991). In Germany it has been classified as a rare, threatened species (Anonymous 1992). I. grammata is also reported from the Russian Far East (Azbukina \& Wasser 1990). In North America it is (called I. albodisca) one of the commonest Inocybe species along the Pacific Coast, less so apparently in the Atlantic coastal region (Grund \& Stuntz 1980).

I. grammata has a long period of fruit body production (Fig. 23). It is one of the species of Inocybe that fruits already early in summer. The earliest Nordic find (from Sweden, Uppland) dates from 12 June. In rainy summers it may produce basidiocarps in early July. Most specimens have been collected between late July and early September. In Finland the fruiting season may extend into early October, in more southern countries (e.g. Denmark, Poland) to mid-October. The two latest specimens examined were collected in Seattle, Pacific Coast of North America.

\section{Specimens examined}

Finland. Åland: Finström, 1993 Vauras 8525 (TUR); Sund, 1991 Vauras 5600 (TURA). Varsinais-Suomi: Koski Tl, 1987 Heinonen 26-87 (TUR), 1989 Heinonen 83-89 (TUR), 1991 Heinonen \& Vauras 5978 (TURA); Lohja, 1990 Vauras 4407 (TURA); 1993 Kytövuori 93$569(\mathrm{H})$; Nagu, 1993 Vauras 8576 (TUR); Pargas, 1987 Vauras 2641 * (TUR). Uusimaa: Askola, 1996 Höijer 1913 (TURA); Ekenäs, 1957, 1960, 1961, v. Schulmann (H), 1962 v. Schulmann (H, as I. oblectabilis); Helsinki, 1937 Frey (H), 1949 Malmström (H), 1981 Saarenoksa 23881, 26581 (H), Saarenoksa \& Vauras 1029 (TURA), 1983 Saarenoksa 24383 (H), 1984 Saarenoksa 07984 $(\mathrm{H}), 1985$ Saarenoksa $21685 *(\mathrm{H}), 1987$ Kytövuori $87526(\mathrm{H}), 1988$ Kytövuori 88-033 (H); Kauniainen, 1945 Nyberg (H); Kirkkonummi, 1993 Kytövuori 93$1473(\mathrm{H})$; Porvoo, 1978 Issakainen $(\mathrm{H})$; Sibbo, 1982 Saarenoksa $33082(\mathrm{H})$; Vantaa, 1983 Saarenoksa 41783 (H). Etelä-Häme: Hattula, 1993 Kytövuori 93-307 (H); Heinola rural municipality, 1977 Vainio $24(\mathrm{H})$;
Hämeenlinna, 1990 Vauras 5060 (TURA); Iitti, 1980 Vauras 699 (TURA); Korpilahti, 1994 Vauras 9344 (TURA); Lammi, 1991 Storbacka (TURA); Loppi, 1954 Tuomikoski (H); Orivesi, 1996 Issakainen (TURA); Somero, 1996 Vauras 11261, 11262F (TURA); Tampere, 1988 Laaksonen 2 (OULU), Kosonen \& Vauras 3101 (TUR), Vauras 3181 (TURA); Ypäjä, 1990 Vauras 5204 (TURA, WBS). Etelä-Savo: Mikkeli, 1987 Vauras 2678 (TURA), 2820F * (C, TUR, TURA); Mikkeli rural municipality, 1992 Kytövuori 92$2708(\mathrm{H})$. Pohjois-Häme: Saarijärvi, 1986 Härkönen (TURA); Äänekoski, 1985 Storbacka 85115 (TURA, VLA), 1986 Vauras 2134 (TURA), 2304 * (OULU). Pohjois-Savo: Iisalmi, 1990 Vauras 4581 * (TURA); Joroinen, 1987 Kytövuori 87884 (H); Juankoski, 1994 Vauras 9217; Kuopio, 1906 Linkola (TUR), 1973 Hakala* (KUO), 1979 Vauras 497, 499 (TUR), 1980 Vauras \& Huhtinen (TUR), Vauras 661F * (TURA), $768 *, 776$ * (TUR), 1981 Vauras $908 F *$ (TUR, TURA), $912 F$ (TURA), $988 *, 1099,1130$ (TUR), 1982 Vauras 1351 (TURA), 1984 Ruotsalainen * (KUO), 1992 Höijer (TURA), Kinnunen (TURA), Vauras 6784, 6827 (TURA), 1994 Ruotsalainen 3606 (TURA), Vauras 9420 (TURA). Lapinlahti, 1956 v. Schulmann (H); Leppävirta, 1993 Ruotsalainen 3285 (TUR); Nilsiä, 1994 Ruotsalainen 3721 (TURA); Siilinjärvi, 1977 Heikkilä * (KUO), 1980 Leinonen (M), 1985 Ruotsalainen (TURA), 1990 Ruotsalainen 1700 (TURA); Vehmersalmi, 1994 Vauras 9196F. Pohjois-Karjala: Eno, 1996 Vauras 11604 (TURA); Lieksa, 1994 Salo (Joensuu Forestry Research Station). Keski-Pohjanmaa: Alaveteli, 1982 Storbacka (OULU); Kokkola, 1988 Storbacka * (TURA), 1990 Storbacka \& Vauras 4949 (TURA); Uusikaarlepyy, 1993 Jakobsson 305 (H); Veteli, 1990 Kytövuori 90-1099 (H). Kainuu: Paltamo, 1974 E. Ohenoja (OULU). Oulun Pohjanmaa: Kiiminki, 1990 M. Ohenoja (OULU), 1991 E. Ohenoja et al. (OULU); Muhos, 1966 Ulvinen * (OULU), 1991 E. Ohenoja (OULU). Oulu, 1965 Ulvinen (OULU); Pudasjärvi, 1975 E. Ohenoja * (OULU). Perä-Pohjanmaa: Rovaniemi rural municipality, 1990 Vauras 4908 (TURA). Koillismaa: Kuusamo, 1970 Ulvinen * (OULU), 1978 Jakowlev \& Söderholm (OULU, TURA), 1979 Ulvinen et al. * (OULU), 1993 Ruotsalainen 3222 (TUR), 1996 Vauras 11686, 11719 (TURA). Kittilän Lappi: Kolari, 1970 M. \& E. Ohenoja * (OULU). Sompion Lappi: Pelkosenniemi, 1985 E. Ohenoja * (OULU). Enontekiön Lappi: Enontekiö, 1990 Vauras 4749, 4800 (TURA), 1995 Ruotsalainen \& Vauras $10541 F$ (TURA). Austria. Gurgler Tal, Poschach, 1971 Stadelmann * (M, as I. trivialis). Hasental bei Hall, 1948 Chaida (M). Kärnten, Mölltal, 1978 L. Stridvall 78-15I (Herb. LAS). Maria Waldrast, 1949 Moser (M). Tirol, Lienz, Dölsach, 1978 L. Stridvall 78-150 (Herb. LAS). Ötztal, Sölden, 1971 Stadelmann (M). Belgium. Bolderberg, 1994 Volders 94129 (TURA). Czech Republic. Mährish-Ostrau, Ostrava, 1970 Veselský (M). Stráznice, 1955 Smarda (M). Denmark. Western part of Jylland: Randbølgård Plantage E of Vandel, 1989 Vesterholt 891091 (TURA); Bønstrup SE of Varndrup, 1994 Taft (TURA). Fyn: Langes $\emptyset, 1940$ J. Lange (C). Estonia. Harju distr.: Tallinn, 1985 Shtshukin (TAA 141703, as I. glabrodisca). Saaremaa: Viidu, 1981 Shtshukin (TAA 114585), 1993 Vauras 8800 (TUR). Faröes. Streymoy, 
Tórshavn, 1988 Vesterholt PRV 776 * (Museum of Natural History in Tórshavn). France. Doubs, Bois, Le Russey, 1938 Favre (G). Germany. Baden-Württemberg: Schwäbisch Gmünd, 1967 Schwöbel (M), 1974 Stangl (M). Bavaria: Augsburg, Aystetten, 1963 Stangl (M), Feigenhofen, 1969 Stangl (M), Lützelburg, 1964 Stangl (M), Mertingen, 1962 Stangl (M), Wellenburg, 1970 Stangl (M, 2 ex.); München, Anzing, 1973 Einhellinger (M); Landsberg, Kaltenberg, 1968 Bresinsky (M). Saarland: Völklingen, 1972 Derbsch (M). Sulzen, bei Weidhausen, 1974 Engel (M). Hungary. Scepusii, year not indicated, Kalchbrenner (UPS, Herb. E. Fries, as I. scabella). Italy. Alto Adige: Trento, Gocciadoro, 1899 Bresadola (S), Rabbi, 1900 Bresadola (S). Latvia. Cesis distr.: Gauja National Park, 1996 Kalamees \& Vauras 11985 (TURA). Netherlands. Friesland: Schiermannikoog, 1986 Keizer * (WBS). Gelderland: Wageningen Hoog, 1986 Dam (WBS). Noord-Brabant: Dorst, 1954 Jansen, Bas \& Maas Geesteranus (H). Locality not indicated, 1967 Buning (M). Norway. Akershus: Nannestad, 1977 Gulden $220 / 77$ (O); Oslo, 1921 Egeland * (O), 1925 Thomle (O). Buskerud: Hole, 1967 Gulden 209-67 (O). Møre og Romsdal: Sunndal, 1991 Weholt (TURA). Oppland: Dovre, 1964 Lysebraate (O). Sør-Trøndelag: Oppdal, 1991 Ruotsalainen \& Vauras 5699 (TURA). Nord-Trøndelag: Levanger, 1979 Brandrud 198-79 (O). Nordland: Rana, 1976 Nannfeldt (O), Schumacher (O). Troms: Kåfjord, 1992 Kytövuori 92-519 (H). Poland. Ostpoland, Bialowieski, 1973 Barkman (WBS). Russia. Baical, Listvenitchnoje, 1902 Lönnbohm (H). Krasnodar Krai, Reservatum Caucasia, Umpör, 1976 Pihlik \& Vaasma (TAA 95141). Sweden. Skåne: Fjälkestad, 1986 Örstadius 53-86 * (TURA); Ravlunda, 1950, 1954 Andersson (LD); Österslöv, 1943 Andersson (LD); Ö. Sönnarslöv, 1954 Andersson (LD). Bohuslän: Fjällbacka, 1989 L. \& A. Stridvall 89-40 * (Herb. LAS); Naverstad, 1980 L. Stridvall 80-203 (Herb. LAS); Tossene, 1985 Jacobsson 85058 (GB); Uddevalla, 1985 L. Stridvall 85-159 (Herb. LAS); Ödsmål, 1980 Jacobsson 80201 (GB). Västergötland: Erska, 1980 L. Stridvall 80-133 (Herb. LAS); Trollhättan, 1980 L. Stridvall 80-355 (Herb. LAS), 1981 L. Stridvall 81-192 (Herb. LAS); Vänersnäs, 1983 Bohlin (GB); Västra Tunhem, 1980 L. Stridvall 80-173 * (Herb. LAS), 1981 L. Stridvall 81-73 (Herb. LAS). Småland: Femsjö, 1943 Lundell 3480 * (Fungi Exs. Suecici 2305, C, PC, S, UPS). Värmland: Karlstad, 1943 Svensson (UPS); Södra Råda, 1984 Carlstedt (GB). Uppland: Djurö, 1947 Rydberg (S); Stockholm, 1898 Romell (S); Uppsala, 1909 v. Post (S). Medelpad: Selånger, 1984 Eriksson \& Wimo (GB). Jämtland: Åre, 1984 Jacobsson 84031 (GB). Switzerland. Tamangur dadora, 1944 Favre *(G). Ukraine. Reservatum Carpatia, Hoverla, 1972 Kalamees (TAA 80114, 80204). United States. Washington: King County, Seattle, 1942 Stuntz 1291 * (TURA), 1944 Stuntz 1596 * (TURA). Lewis County, 1973 Van de Bogart * (TURA).

\section{Discussion}

Inocybe grammata is readily distinguished macroscopically by its silvery grey colour when young, later incarnate-vinaceous pileus with cream-coloured centre, and its reddish, totally white-pruinose stipe, often with emarginate bulb. Also dried specimens can usually be identified macroscopically. Microscopically the species is recognized by its thick-walled cystidia and relatively small subangular spores with mainly obscure nodules.

Kühner (1933) long ago referred to I. grammata and I. albodisca Peck as synonymous. Moënne-Loccoz et al. (1990) nevertheless recently treated them as separate species.

In the absence of authentic specimens left by L. Quélet, the painting of I. grammata in the original paper is selected here as the lectotype (Art. 8.3., 9.2.). It shows a fruit body with characters typical of a majority of I. grammata populations: pileus with yellowish centre, incarnate in outer part and pale at margin, and pruinose stipe, which is longitudinally striate, red-tinged and bulbous. The bulb is not drawn as emarginate, but this is not a constant feature of I. grammata. Stangl's (1979) citation of Bresadola's material (Cavareno, Prov. Trento, 23.8.1903 Bresadola) as "Typus" represents an erroneous neotypification (Art 7.11.), because original material (illustration) is present.

The type material of I. albodisca (Fig. 4) is an excellent match to European specimens. It shows the following microscopical characters. Spores 7.5- $\underline{8.4}-9.0(-9.5) \times 5.0-\underline{5.9}-6.5(-7.0) \mu \mathrm{m}, \mathrm{Q}=$ $1.25-1.42-1.6$, with obtusely nodulose outline. Basidia 24-26×7-8 $\mu \mathrm{m}, 4$-spored. Pleurocystidia 50-63×18-21 $\mu \mathrm{m}$. Cheilocystidia 54-68 × 15-23 $\mu \mathrm{m}$. Caulocystidia 68-70 $\times 20-22 \mu \mathrm{m}$.

Grund \& Stuntz (1980) emphasize that $I$. grammata (as I. albodisca) shows constant macroscopic features in North America. However, its spores seem to be smaller in populations along the Pacific Coast. According to Stuntz (1947), the spores of collection 379 (WTU) from Washington State measure only 6-7.5 $\times 4$ $6 \mu \mathrm{m}$. My own study on the material from Washington State gave the following measures of spores ( $\mathrm{n}=60$, from 3 collections): 7.0-7.9$9.0(-9.5) \times 5.0-5.6-6.5 \mu \mathrm{m}$, range of mean values 7.8-8.0 $\times 5.5-5.6 \mu \mathrm{m}, \mathrm{Q}=(1.25-) 1.3-1.42-$ $1.55(-1.7)$. These are the shortest values in the material of $I$. grammata examined by me. However, the collections are macroscopically, and in their cystidia, identical with European specimens, and I consider them conspecific. 

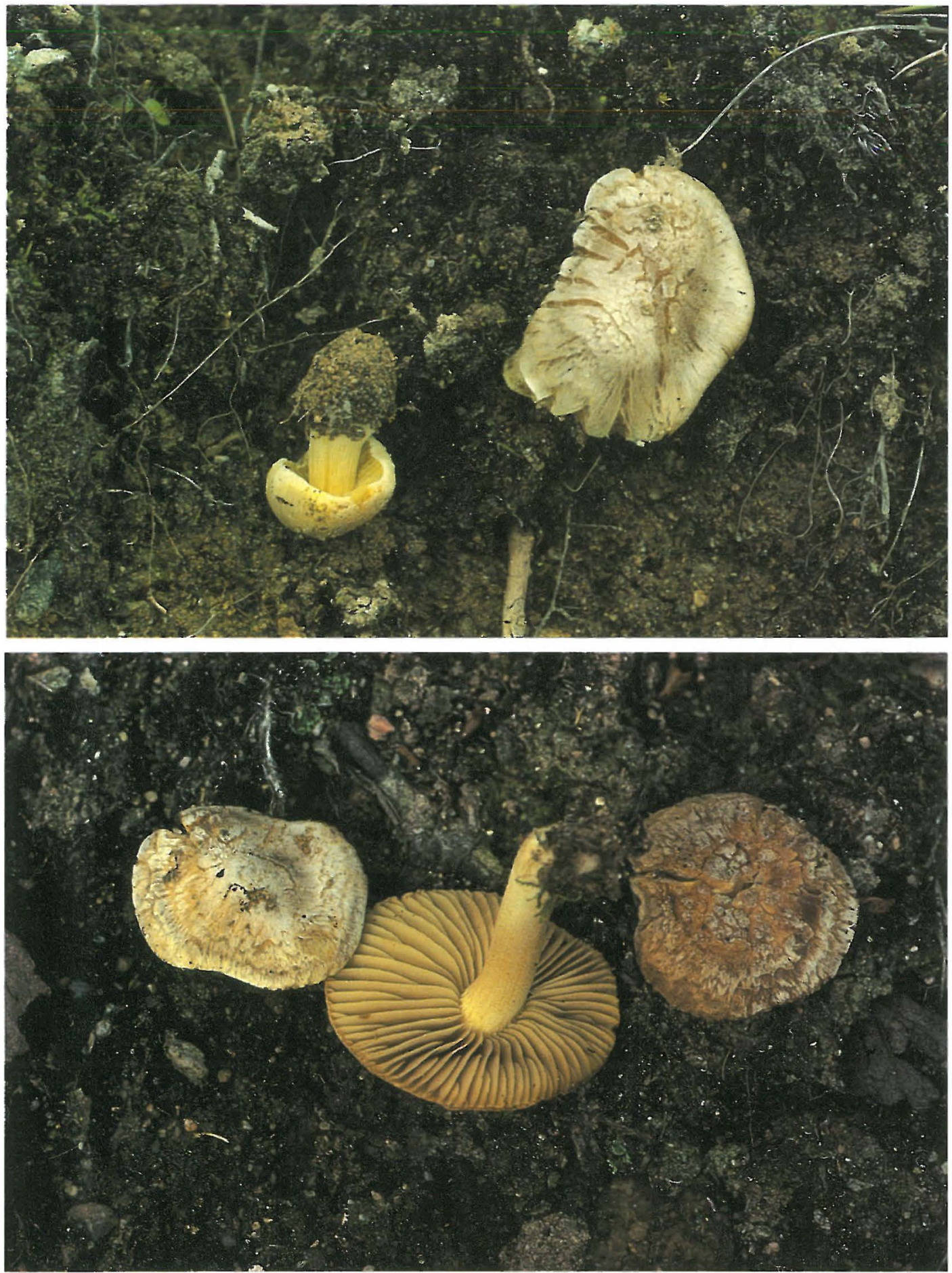

Figs. 7-8. Inocybe argenteolutea is characterized by the pale pileus and the yellow lamellae and stipe. - 7: Young fruit bodies in situ by path at the type site (Vauras $2245 F$ ), $X$ approx. 2.1. - 8: Fruit bodies of the type specimen, $\times$ approx. 2.2 . 


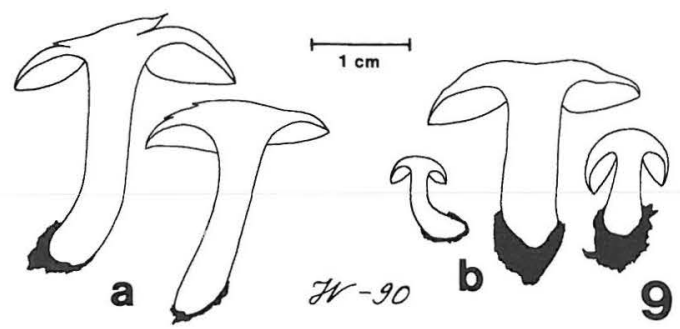

Fig. 9. Fruit bodies of Inocybe argenteolutea,

$9 \times 1$. - a) Part of holotype, b) from Vauras $2245 F$
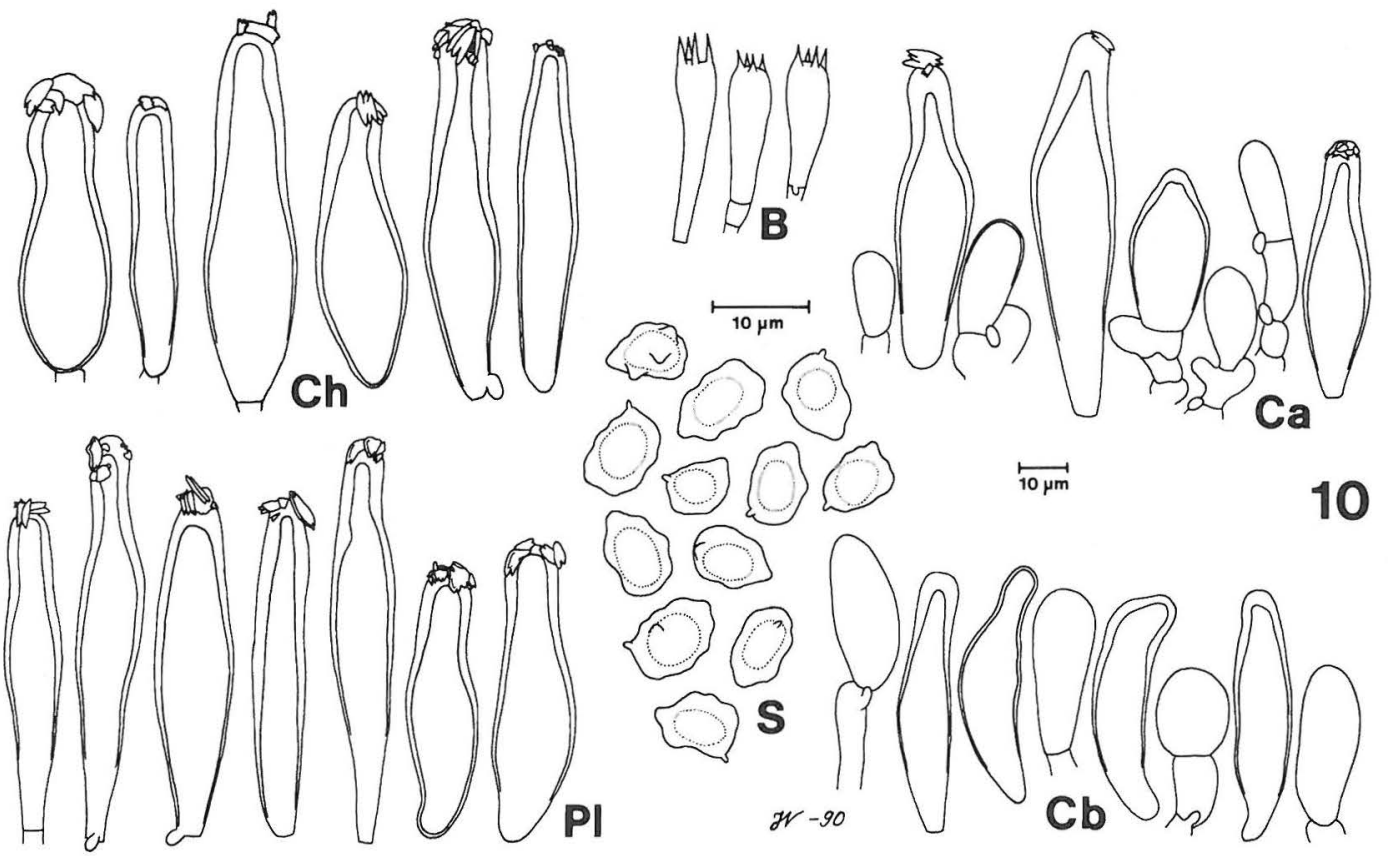

Fig. 10. Microscopical characters of Inocybe argenteolutea (holotype). For symbols and scales see Figs. 3-5.

The original description of I. hiulca (Fr.) Gill. (Fries 1838) is too scanty to be interpreted. For example, "stipite... apice albo-pruinoso" does not fit to I. grammata, because the stipe of that species is pruinose in its whole length.

Among others, I. grammata has sometimes been confused with I. umbratica Quél., I. paludinella Peck and I. argenteolutea Vauras. The first two species differ from I. grammata in their lack of red tinges on fruit bodies, in the more crowded lamellae and shorter pleurocystidia, and in their different shapes of spores. The species described as "Inocybe sp." (Stangl 1989:282, Fig. 111, Pl. 35/4) and as related to $I$. grammata, may be conspecific with I. mixtilioides Kuyper nom. prov. (in Krieglsteiner 1989). The diagnostic characters of $I$. argenteolutea are described later in this paper.

Inocybe argenteolutea Vauras, spec. nova - Figs. 7-11, 17, 23

Pileus $0.8-2.3 \mathrm{~cm}$ latus, primum ex velipelle conspicuo argenteo-griseus, posterius griseoloflavus, dein flavo-brunneus. Lamellae usque ad $5 \mathrm{~mm}$ latae, primum flavae, citreae, posterius brunneo-flavae. Stipes $0.8-2.5 \mathrm{~cm}$ longus, $2.5-$ $6 \mathrm{~mm}$ crassus, subaequalis, brunneo-flavus, 


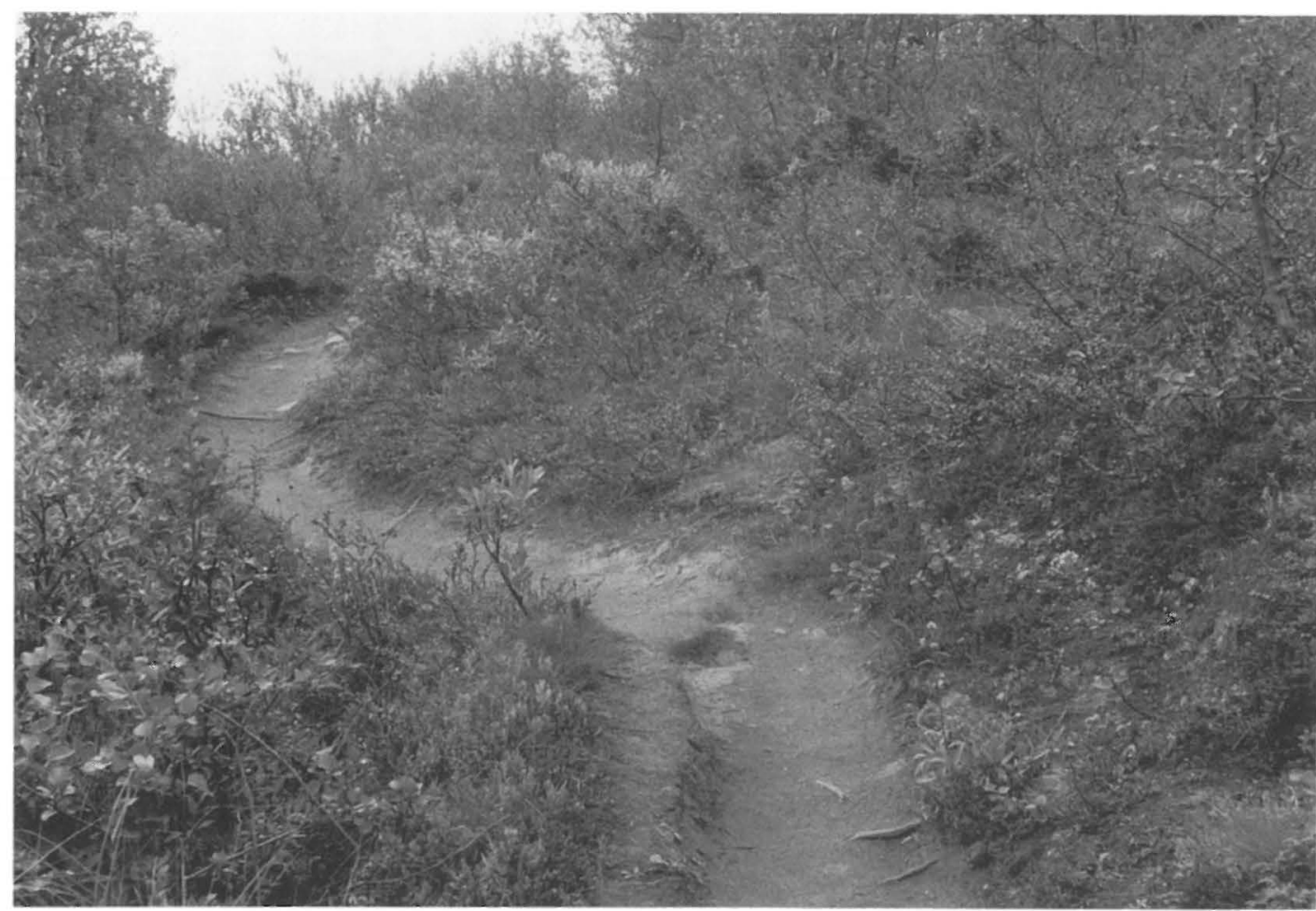

Fig. 11. Type site of Inocybe argenteolutea in mountain birch forest at sandy margin of path, photographed 21.VIII.1995.

omnino pruinosus. Contextus pilei et stipitis citreus, brunneo-flavus, albolutescens vel subalbus, odore sicut spermatium. Sporae (7.0-)7.5$9.0(-10.0) \times(4.5-) 5.0-6.0(-6.5) \mu \mathrm{m}$, angulatae, verruculis plerumque indistinctis. Pleurocystidia (45-)50-80(-96) $\times 11-22(-25) \mu \mathrm{m}$, nonnihil ventricosa. Caulocystidia per totam longitudinem stipitis praesentia. In montibus Fennoscandiae, in sabulo persubtile, cum Betulis Salicibusque.

Holotype: Finland, Enontekiön Lappi, Enontekiö, Kilpisjärvi, near the parking area at Malla Strict Nature Reserve, between lakes Kilpisjärvi and Siilasjärvi, open subalpine birch forest, by path on fine sand, near Betula pubescens subsp. czerepanovii, B. nana, Salix phylicifolia, S. glauca, Phyllodoce caerulea, Empetrum nigrum, Vaccinium vitis-idaea, V. myrtillus, Hieracium alpinum, Solidago virgaurea, Vahlodea atropurpurea, Inocybe lacera var. lacera and Xerocomus lanatus, Grid $27^{\circ} \mathrm{E}:$ 76771:2528, alt. ca. $485 \mathrm{~m}$,
7.VIII.1985 E. Bendiksen, K. Metsänheimo \& O. Skifte (TURA 2360; isotype in $\mathrm{H}$ ).

Pileus $0.8-2.3 \mathrm{~cm}$ in diam, $3-8 \mathrm{~mm}$ high, hemispherical to broadly conical, later plano-convex, broadly umbonate or not umbonate, exceptionally slightly depressed, margin often partly inflexed; surface when young moderately smooth to slightly felty-fibrillose, later partly squarrose or breaking up to squares, disc silvery yellowgrey $(75 \mathrm{M})$, margin greyish brown-yellow (77M) to yellow-brown (60M), velipellis conspicuous.

Lamellae up to $5 \mathrm{~mm}$ broad, moderately crowded, not or indistinctly ventricose, broadly to narrowly adnate to adnexed, when young yellow (85L) to lemon yellow, later brown-yellow $(80 \mathrm{M}-\mathrm{N}), 85 \mathrm{M})$; edge fimbriate, mostly concolorous, infrequently brownish.

Stipe $0.8-2.5 \mathrm{~cm}$ long, $2.5-6 \mathrm{~mm}$ wide, equal to somewhat clavate, bulb lacking; solid, pale brown-yellow to brown-yellow (87L), pruinose all over, longitudinally striate. 
Cortina not seen.

Context in pileus when young lemon yellow to pale yellow, later pale yellow to whitish, where broken pale brown-red; in stipe when young lemon yellow $(80 \mathrm{M})$, brown-yellow (85L) to pale yellow, later pale yellow to whitish. Smell spermatic.

Spores (7.0-)7.5- $\underline{8.4-9.0(-10.0) \times(4.5-)}$ $5.0-5.5-6.0(-6.5) \mu \mathrm{m}$, total range of mean values 8.3-8.8 $\times 5.2-5.7 \mu \mathrm{m}, \mathrm{Q}=(1.3-) 1.4-1.55-$ $1.7(-1.8)$, total range of mean $\mathrm{Q}$ values $=1.51-$ 1.64 (210 spores from 7 collections); subangular, with small nodules. Basidia 25-37 $\times 8-11$ $\mu \mathrm{m}$, clavate, 4-spored.

Pleurocystidia (45-)50-63-80(-96) × 1116-22(-25) $\mu \mathrm{m},(\mathrm{n}=51$, from 7 collections), somewhat ventricose, mostly crystalliferous, base with a downward-tapering pedicel or rounded, wall pale yellow to yellow, up to $3 \mu \mathrm{m}$ thick, often extending as thick to base of pedicel; frequent. Cheilocystidia 30-76 × 10-21(-25) $\mu \mathrm{m}$, rather frequent. Paracystidia clavate, thinwalled, colourless, scarce.

Caulocystidia occurring down to base of stipe, up to $75 \mu \mathrm{m}$ long. Cauloparacystidia numerous, a minority thick-walled.

\section{Distribution, ecology and phenology}

Inocybe argenteolutea seems to be a rare boreal species occurring at higher localities of mountains and northern uplands of Fennoscandia. All finds have been made in the northern boreal zone, mostly in Northern Finland and Norway, and one in southern Norway (Fig. 17). The lastmentioned locality is ca. $1100 \mathrm{~m}$ above sea level. In Northern Finland the species has been collected at elevations of, for example, ca. $100 \mathrm{~m}$ and $485 \mathrm{~m}$.

The species grows in open localities in mountain birch forests and above the timberline, e.g. in lichen heaths. The most probable mycorrhizal hosts are Betula and Salix. It appears in small groups or solitary in dry, poor sites, by paths and at margins of roads, favouring fine sand. The $\mathrm{pH}$ reaction of the surface soil of the type site was 5.5.

According to the material examined, the fruiting period of $I$. argenteolutea is short, starting in late July and ceasing in mid-August. At the type site the species seems to fruit fairly regularly. During visits to the Kilpisjärvi area in Finnish Lapland in 1985, 1986, 1987, 1990 and 1995, I failed to find the species in 1987, which was a cold and rainy year with failure of crops in the Nordic countries, and in 1995, when the summer was dry.

\section{Specimens examined}

Finland. Enontekiön Lappi: Enontekiö, Kilpisjärvi, 1985 (type) *, 1986 Vauras $2203 *$ (TURA 2361), Vauras $2245 \mathrm{~F} *$ (TURA 2362, GB), 1990 Vauras 4711 (TURA 2363). Inarin Lappi: Utsjoki, church village, Ailigas, 1964 Kankainen * (TUR 20837), margin of road, 1968 Kankainen * (TUR 20977). Norway. Oppland: Vågå, Hauskelie, in track in lichen heath, 1969 Lange \& Gulden 386-69 * (O). Finnmark: Tana, Rastigaissa, regio alpina, 1966 Kankainen* (TUR 20935).

\section{Discussion}

Inocybe argenteolutea is characterized by its yellow fruit bodies and the copious silvery velipellis. The microscopical characters are fairly similar to those of I. grammata, and for this reason the species was reported from Norway by Gulden \& Lange (1971) as I. grammata forma. Because the authors had only one collection, they refrained from describing a new taxon.

The yellow, partly lemon-tinted fruit bodies make $I$. argenteolute $a$ easy to recognize and distinguish from $I$. grammata. Further dissimilarities to I. grammata are its spermatic smell and some microscopical characters. The outline of spores is different: there are more nodules and they are smaller than on spores of $I$. grammata. Moreover, the pleurocystidia are somewhat narrower and their walls are thinner. I. argenteolutea is nevertheless closely related to I. grammata. Both species grow by paths in subalpine localities, although I. argenteolutea has a much narrower ecology. I. argenteolutea also has a more restricted distribution, occurring only in localities near the timberline. It seems to favour poorer sites than I. grammata.

I. paludinella Peck is a slender species growing in moist sites. It has shorter (43- $\underline{53}-65 \times 11$ 15-19 $\mu \mathrm{m})$ pleurocystidia and more distinctly nodulose spores than $I$. argenteolutea.

Inocybe pargasensis Vauras, spec. nova Figs. 12, 14-17, 23

Pileus $0.7-3.5 \mathrm{~cm}$ latus, pallidus, compositis ex griseo, subflavo, brunneolo et rubello vario 

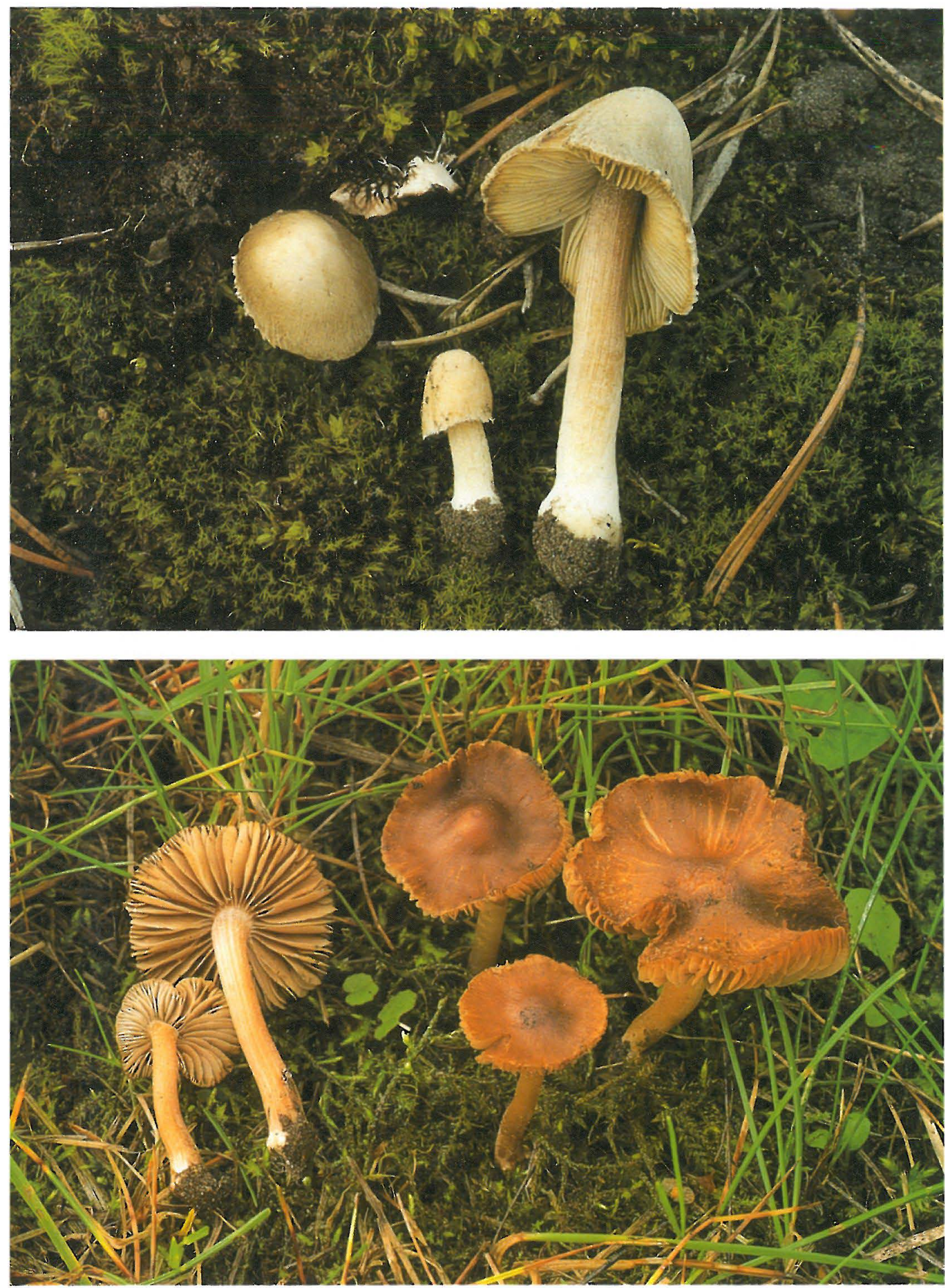

Figs. 12-13. - 12: Fruit bodies of Inocybe pargasensis (holotype) in situ, $X$ approx. 1.9. - 13: Fruit bodies of Inocybe decemgibbosa, $X$ approx. 1.4. Finland, Varsinais-Suomi, Lohja 10.VIII.1993 Vauras 8115F (TUR, TURA). 

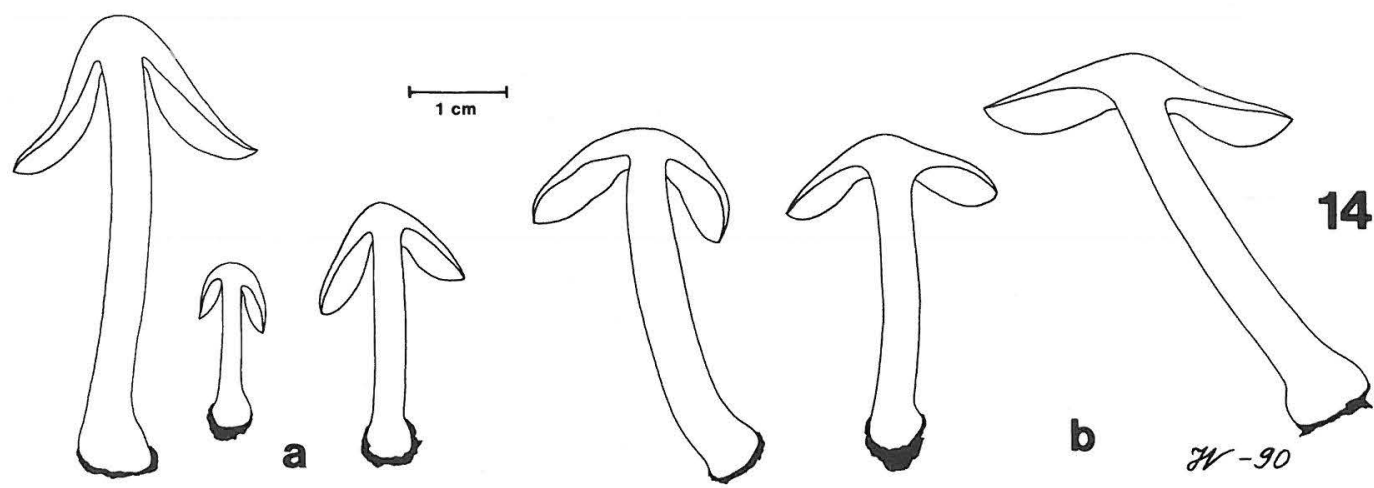

Fig. 14. Fruit bodies of Inocybe pargasensis, $\times 1$. - a) from holotype, b) from Vauras 3216.

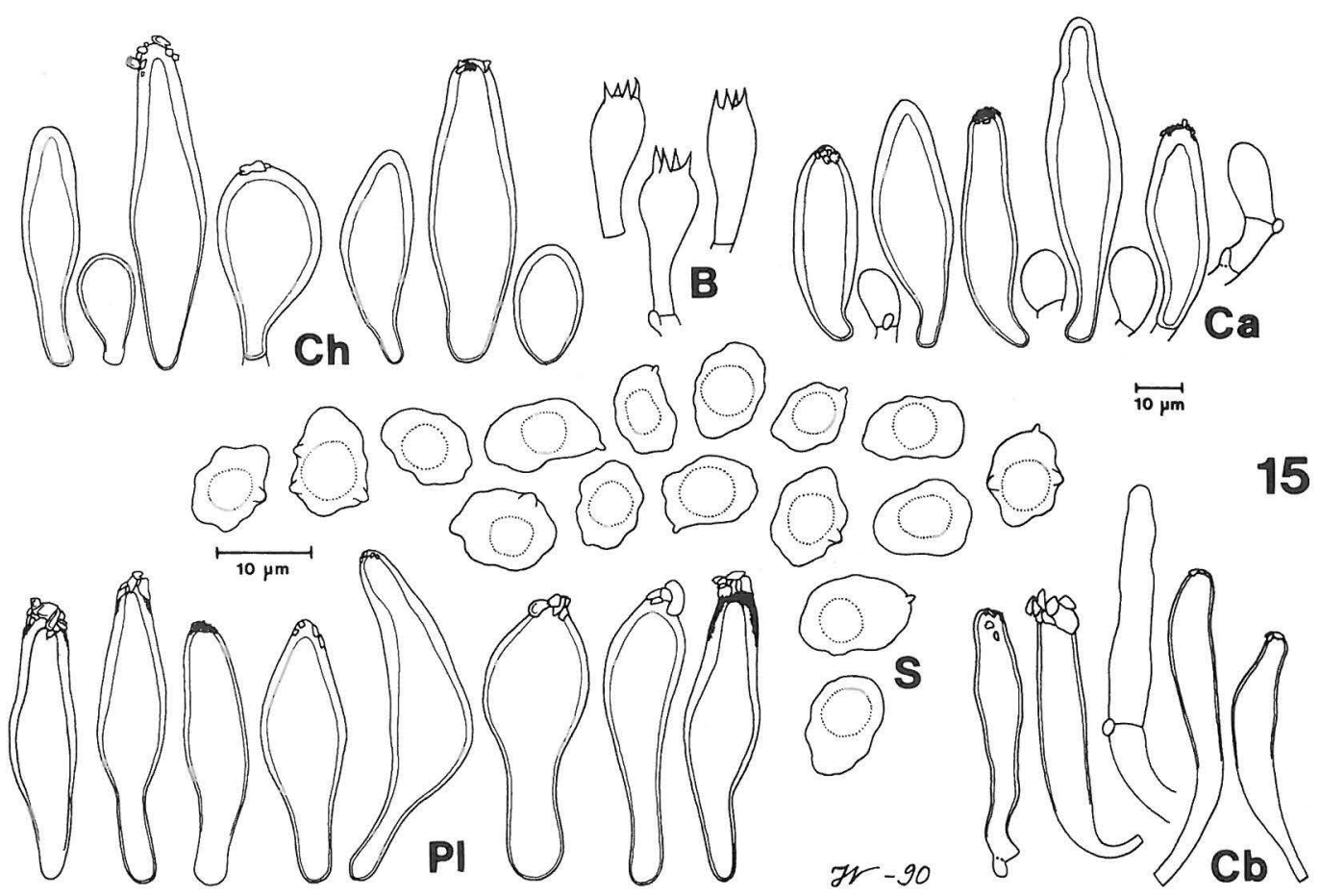

Fig. 15. Microscopical characters of Inocybe pargasensis (holotype). For symbols and scales see Figs. 3-5.

modo permixtis. Lamellae usque ad $4 \mathrm{~mm}$ latae, initio albido-griseolae, dein griseo-brunneae. Stipes $1.5-4.5 \mathrm{~cm}$ longus, $2-5 \mathrm{~mm}$ crassus, cylindraceus vel basim versus leviter incrassatus, basi bulbosus; rubellus vel subfulvus, fere omnino pruinosus. Contextus odore spermatico. Sporae (8.0-)9.0-11.5(-12.5) × (5.5-)6.0-8.0(-9.0) $\mu \mathrm{m}$, tuberculatae, tuberculis obtusis et saepe indistinctis. Pleurocystidia (45-)52-74(-78) $\times 13-21(-26) \mu \mathrm{m}$, nonnihil ventricosa, ad basem rotunda. Caulocystidia per fere totam longitudinem stipitis praesentia. Ad terram calcaream.

Holotype: Finland, Varsinais-Suomi, Pargas, Storgård, Malmnäs, between Furuvik and the limestone processing plant "Kalkkitehdas", on a 


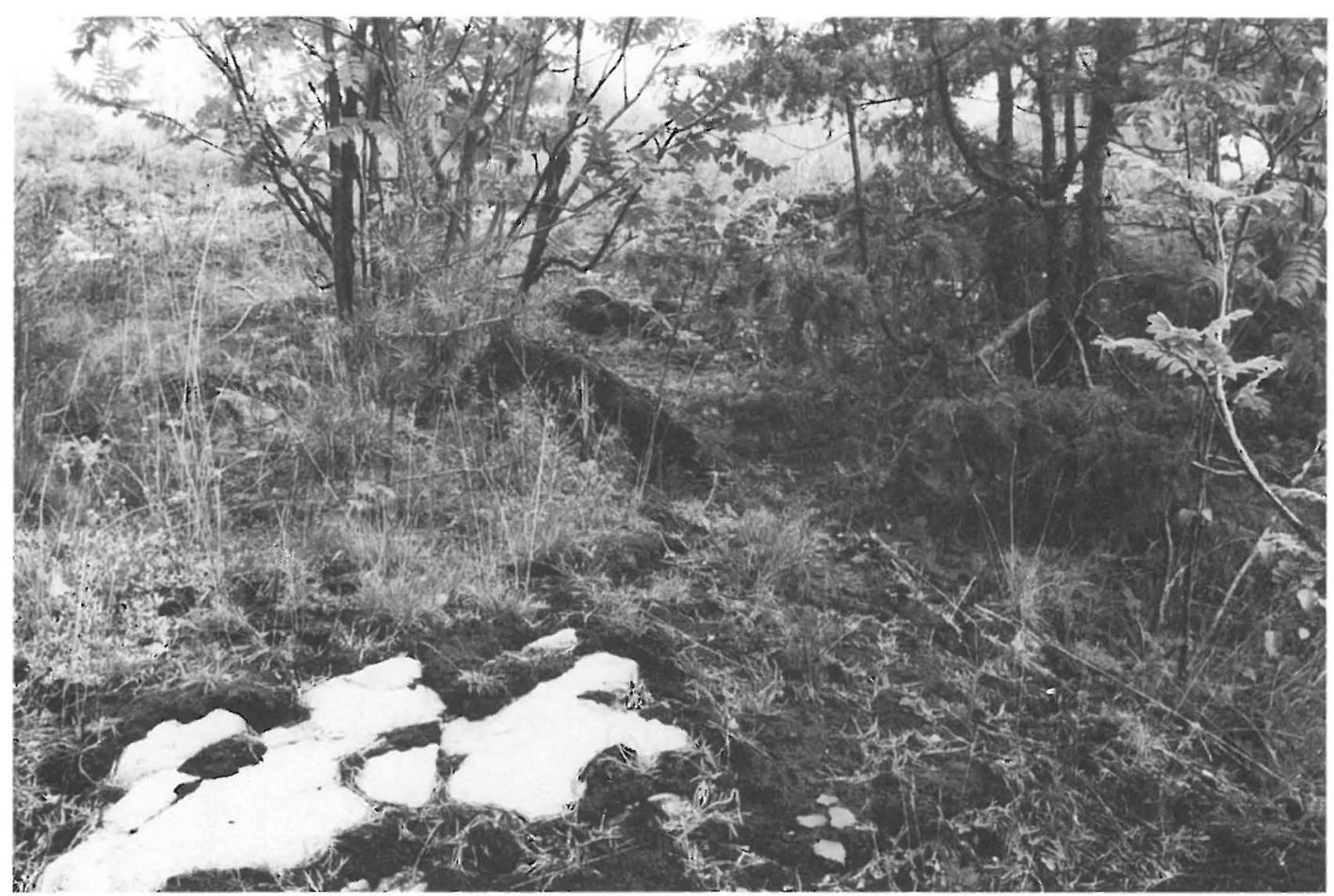

Fig. 16. Type site of Inocybe pargasensis on rocky outcrop near a limestone processing plant. The bare rock in the front is white because of the lime dust from the plant. Photograph 5.VIII.1989.

rocky outcrop, on thin humus and mosses, margin of dry heath forest in a lime dust area, with Pinus sylvestris, Betula, Populus tremula, Sorbus aucuparia, Juniperus communis, Fragaria vesca, Antennaria dioica, Artemisia campestris and Suillus luteus, Grid 27 E: 66961:2403, alt. 20 m, 12.IX.1986 J. Vauras 2434F (TURA 2353).

Pileus $0.7-3.5 \mathrm{~cm}$ in diam, 7-21 $\mathrm{mm}$ high, when young hemispherical to paraboloid, later conicoconvex, subumbonate or without umbo, margin mostly straight; smooth around disc, margin slightly felty-fibrillose, later radially rimose, often slightly appendiculate exceeding lamellae; colours fairly pale, when young disc whitish to grey-yellowish $(71 \mathrm{~L})$, with velipellis, at margin somewhat more grey and darker (70M-71L), also later disc most pale (71M, 69M, 91K), at margin brown-grey, pale greyish yellow-brown (20M) to grey-reddish (49M).
Lamellae up to $4 \mathrm{~mm}$ broad, moderately crowded to subdistant, ventricose, narrowly adnate to adnexed, when young whitish, then pale grey, pale brown-grey $(70 \mathrm{M}, 75 \mathrm{M})$ to greybrown $(69 \mathrm{~N})$; edge fimbriate, concolorous, occasionally partly brown.

Stipe $1.5-4.5 \mathrm{~cm}$ long, 2-5 mm wide, bulbous but without marginate bulb, bulb up to $9 \mathrm{~mm}$ wide; solid, reddish $(53 \mathrm{M}, 55 \mathrm{M})$, reddish yellow-brown $(67 \mathrm{M})$, yellow-brown $(65 \mathrm{~N}, 60 \mathrm{P})$, apex occasionally dark red, base white; fairly scarcely white-pruinose nearly to base of stipe, longitudinally striate.

Cortina not seen.

Context in pileus whitish, under pileipellis pale brown, in stipe glimmering, when young whitish to reddish, later brown-reddish to brown-yellowish. Smell spermatic.

Spores (8.0-)9.0-10.0-11.5(-12.5) $\times(5.5-)$ $6.0-7.0-8.0(-9.0) \mu \mathrm{m}$, total range of mean values $9.5-10.2 \times 6.8-7.2 \mu \mathrm{m}, \mathrm{Q}=(1.2-) 1.25-$ 
$\underline{1.43}-1.65(-1.8)$, total range of mean $\mathrm{Q}$ values 1.39-1.47 (120 spores from 3 collections); subangular, with few small nodules. Basidia 27-37 $\times 10-15 \mu \mathrm{m}$, clavate, 4-spored.

Pleurocystidia (45-)52- $\underline{62}-74(-79) \times 13-\underline{16}-$ $21(-26) \mu \mathrm{m}(\mathrm{n}=62$, from 3 collections), ventricose, clavate or cylindraceous, mostly crystalliferous, small crystals occasionally abundant at apex, base mostly with fairly thick, rounded pedicel, wall pale yellow to yellow, up to $4 \mu \mathrm{m}$ thick, often extending as thick to base of pedicel; fairly frequent. Cheilocystidia 43-70 × 12-22 $\mu \mathrm{m}$, occasionally totally yellow to yellow-brown, frequent. Paracystidia ovoid to clavate, often thick-walled, colourless, fairly frequent.

Caulocystidia at upper part of stipe similar to cystidia of hymenium, up to $70 \mu \mathrm{m}$ long, at base more cylindrical. Cauloparacystidia numerous, a minority thick-walled, no cauloparacystidia seen at stipe base.

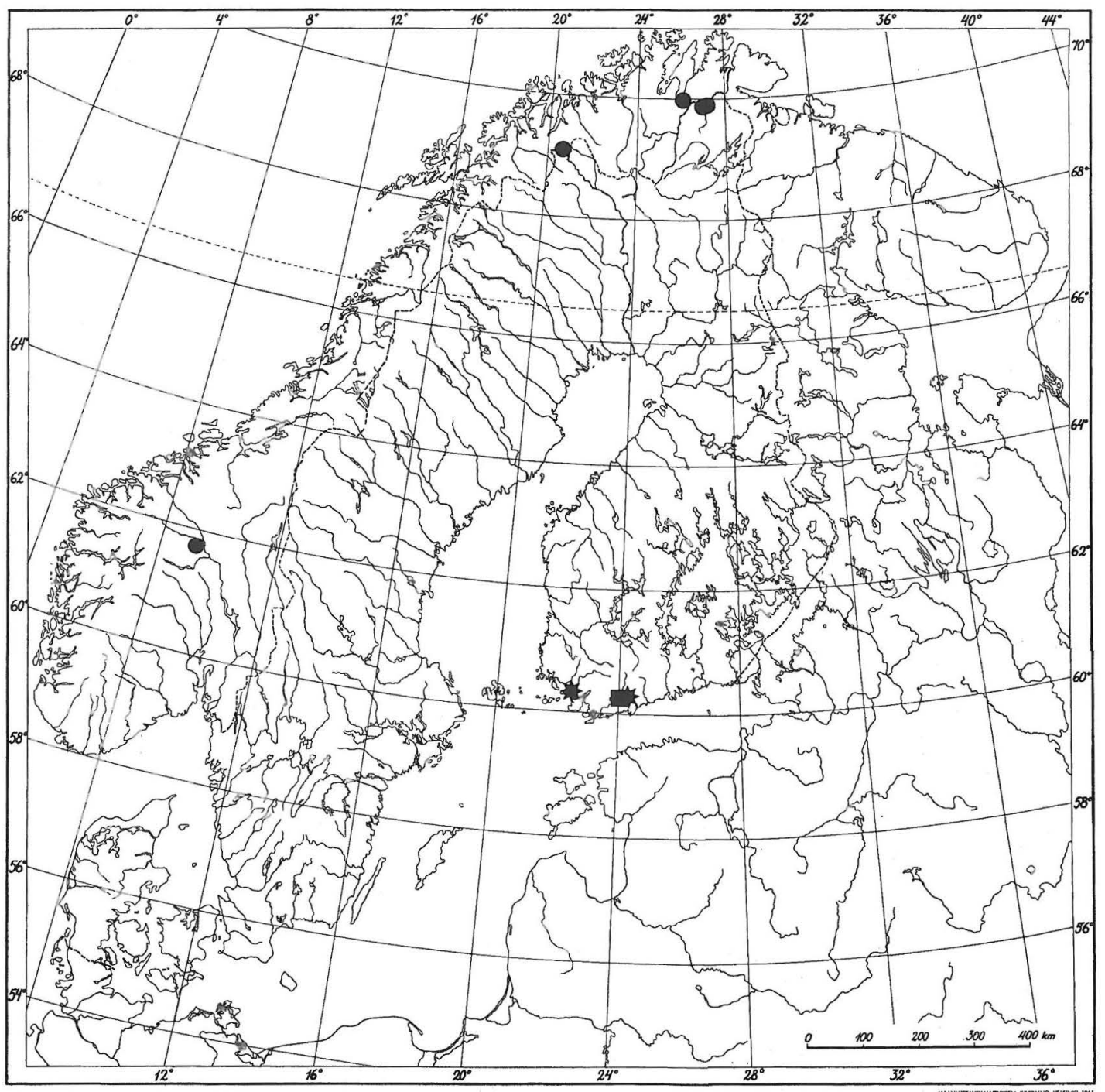

Fig. 17. Distribution of Inocybe argenteolutea $(\mathbf{O})$, I. pargasensis $(*)$ and I. decemgibbosa $(\square)$ in the Nordic countries according to the specimens examined. 


\section{Distribution, ecology and phenology}

Inocybe pargasensis is known only from the towns of Pargas and Lohja, both situated in SW Finland, hemiboreal zone. The distance between the two known growing sites in Pargas is $170 \mathrm{~m}$. Both sites are in dry, gently sloping heath forest dominated by Pinus sylvestris and with scattered Picea abies and Betula. Nearby there are two limestone processing plants, which have emitted lime dust for decades. The soils of the area are noticeably calcareous, and the $\mathrm{pH}$ values of the surface soils (sandy mull) of the two sites range from 7.6 to 7.7 (Table 1).

Other macrofungi collected close by in Pargas include Clitocybe sinopica (Fr.: Fr.) P. Kumm., Helvella acetabulum (L.) Quél., $H$. pedicellata Harmaja, Inocybe leucoblema Kühner, I. melanopus Stuntz, I. oblectabilis (Britzelm.) Sacc. and I. terrigena (Fr.) Kuyper. In the locality Malmnäs the macrofungi species that are abundant and characteristic to calcareous soils include Helvella crispa (Scop.) Fr., Inocybe dulcamara (Pers.) P. Kumm., Russula exalbicans (Secr.) Melzer \& Zvára, Tricholoma terreum (Schaeff.: Fr.) P. Kumm. and T. scalpturatum (Fr.) Quél. Other macrofungi, rare in Finland but found in Malmnäs, include Hebeloma edurum Métrod ex Bon, Helvella leucomelaena (Pers.) Nannf., Inocybe inodora Velen., I. mytiliodora Stangl \& Vauras (Stangl \& Vauras 1988), I. perlata (Cooke) Sacc. (Vauras \& Huhtinen 1986), Mycenella salicina (Velen.) Singer f. bispora Courtec., Peziza succosa Berk. (Huhtinen \& Vauras 1984), Suillus aeruginascens (Secr. ex Opat.) Snell, Tremiscus helvelloides (DC.: Pers.) Donk, Tricholoma aurantium (Schaeff.: Fr.) Ricken and T. fracticum (Britzelm.) Kreisel. This locality is also known for having the largest population of the orchid Ophrys insectifera in Finland (Lampolahti 1991).

I. pargasensis was also found near a limestone processing plant in Lohja. It was growing by a path in a herb-rich forest with Betula pendula, Populus tremula, Corylus avellana, Picea abies and Pinus sylvestris, with Inocybe rimosa. The locality Pähkinäniemi is known for the many rare macrofungi, e.g. Karstenella vernalis Harmaja (Harmaja 1969) and Inocybe fraudans (Britzelm.) Sacc. (Vauras 1989). Recent interesting finds in the locality are Helvella costifera Nannf., I. angulatosquamulosa Stangl,
I. cryptocystis D.E. Stuntz, Melanogaster broomeianus Berk. ex Tul. and Russula fulvograminea Ruots., Sarnari \& Vauras (Ruotsalainen et al. 1997).

I. pargasensis appears to fruit from early July to mid-September, but very rarely. After finding the species in Pargas I have visited the growing sites every year, but in vain.

\section{Specimens examined}

Finland. Varsinais-Suomi: Lohja, Virkkala, Pähkinäniemi, 1996 Vauras 11199 * (TURA 6002); Pargas, Storgård, Malmnäs, 1986 (type) *, 1988 Vauras 3216 * (TURA 2354, GB, TUR).

\section{Discussion}

Rich occurrences of the species of Inocybe are known from areas nearby limestone processing plants in Finland (Vauras 1991). However, nearly all species in such areas are smooth-spored. Only one species with angular-nodulose spores is fairly common in the lime dust areas, i.e. $I$. oblectabilis (in Southern Finland). Much rarer in these areas are I. grammata and I. mixtilis (Britzelm.) Sacc., as also I. pargasensis.

I. pargasensis is characterized macroscopically by the pale colour of the pileus and the reddish to brown-yellow stipe. Microscopically it can be recognized by the subangular spores with obscure nodules and the pleurocystidia with fairly broad and rounded pedicels. At first sight it may be confused with I. grammata, but it differs in its spermatic smell and clearly larger spores. The more robust $I$. oblectabilis has a fairly similar smell to $I$. grammata but differs microscopically in the more abundant and prominent nodules on the spores and the broader walls of the pleurocystidia. I. olida Maire is a pale Mediterranean species lacking a red tinge on the stipe, nor does it show a bulbous stipe base. It has a strong unusual odour and smaller spores (Alessio 1980) than I. pargasensis.

Judging from the descriptions and paintings in Heim (1931) and Alessio (1980) \& Rebaudengo (1980), I. nobilis (R. Heim) Alessio has much in common with I. pargasensis. However, the microscopical drawings of I. nobilis are noticeably different from those of $I$. pargasensis. The outline of the spores of I. pargasensis is fairly rounded, while the spores of I. fibrosa var. 
nobilis in Heim (1931) are more rectangular and show more prominent nodules. Heim (1931) also reported somewhat larger spores. Unfortunately, no cystidia of I. fibrosa var. nobilis are depicted in Heim (1931), and no specimens were available from PC. If the holotype specimen (the only specimen mentioned) of I. fibrosa var. nobilis from France, Savoie, "En petite troupe, parmi les aiguilles, sous les épicéas, environs de Pralognan (Vanoise), août 1929" R. Heim, is not found, the painting 2 in Plate 34 (Heim 1931) should be selected as a lectotype. The neotypification made by Alessio (1980:328), "C. L. Alessio; Pamparato (Castello), 13-IX-1975; specimina typica exsiccata in herbario E. Rebaudengo, Cebae", is not permissible.

I. pargasensis should be included in the list of threatened fungi in Finland, as an endangered species.

Inocybe decemgibbosa (Kühner) Vauras, comb. nov. - Figs. 13, 17-20, 22-23

Basionym: Inocybe oblectabilis forma decemgibbosa Kühner, Bull. Soc. Mycol. France 49:116. 1933. - Lectotype: France, Seine et Marne, Ozoir-la-Ferrière, le long de la route Gare-Ferraudière, fossé 5.VIII.1929 $R$. Kühner "C.ct.gr" (G 451762; selected here).

"Inocybe oblectabilis forma decemgibbosa Kühner \& Boursier": Kühner \& Romagnesi, Flore analytique des champignons supérieurs: 232. 1953. (Erroneous author citation).

Selected illustrations. - Stangl, Hoppea 46: PI. 36, Fig. 3. 1989 (as I. glabrodisca). - Moënne-Loccoz et al., Fungorum Rariorum Icones Coloratae 19: Pl. 152. 1990 (as I. glabrodisca).

Pileus 1.3-3.5 cm in diam, 4-12 mm high, when young obtusely conical, later applanate, without umbo or broadly umbonate, margin straight, later often reflexed and undate; surface mostly smooth, exceptionally subrimulose, especially at margin; date-brown to chestnut brown (45R, 47S, 33R, 35R), disc mostly darkest (29T, 30T, $50 \mathrm{~S})$, but exceptionally palest (55P).

Lamellae up to $5 \mathrm{~mm}$ broad, moderately crowded, ventricose, narrowly adnate, pale grey when young, then pale brown-grey, pale greybrown (70M), finally pale brown (Küppers Y40M30C30); edge fimbriate, concolorous.

Stipe $2.3-5 \mathrm{~cm}$ long, 2-6 $\mathrm{mm}$ wide, bulbous but without marginate bulb, bulb up to $8 \mathrm{~mm}$ wide; solid, pale red-brown to yellowish redbrown, apex white to pale brownish red, bulb white; white-pruinose to base of stipe, longitudinally striate.

Cortina not seen.

Context in pileus whitish, in stipe pale brown, glimmering. Smell indistinct.

Spores (8-)8.5-9.3-10.5(-12) × 6-6.9-8 $\mu \mathrm{m}$, total range of mean values $9.0-9.9 \times 6.8-7.3 \mu \mathrm{m}$, $\mathrm{Q}=(1.15-) 1.2-1.35-1.5(-1.55)$, total range of mean Q values 1.33-1.37 (240 spores from 5 collections); nodulose, mostly with $8-10$ prominent nodules. Basidia $24-37 \times 9-13 \mu \mathrm{m}$, clavate, 4-spored.

Pleurocystidia (41-)46-56-66(-72) $\times(12-)$ $14-18-24(-26) \mu \mathrm{m},(\mathrm{n}=71$, from 5 collections), ventricose, cylindrico-clavate, slenderly fusiform to subutriform, crystalliferous, crystals abundant, base mostly with a downward tapering pedicel, wall pale yellow, up to $3.5 \mu \mathrm{m}$ thick, mostly not extending to base of pedicel; fairly frequent. Cheilocystidia 32-54 × 15-22 $\mu \mathrm{m}$, rather frequent. Paracystidia ellipsoid to pyriform, thin-walled, colourless, scarce.
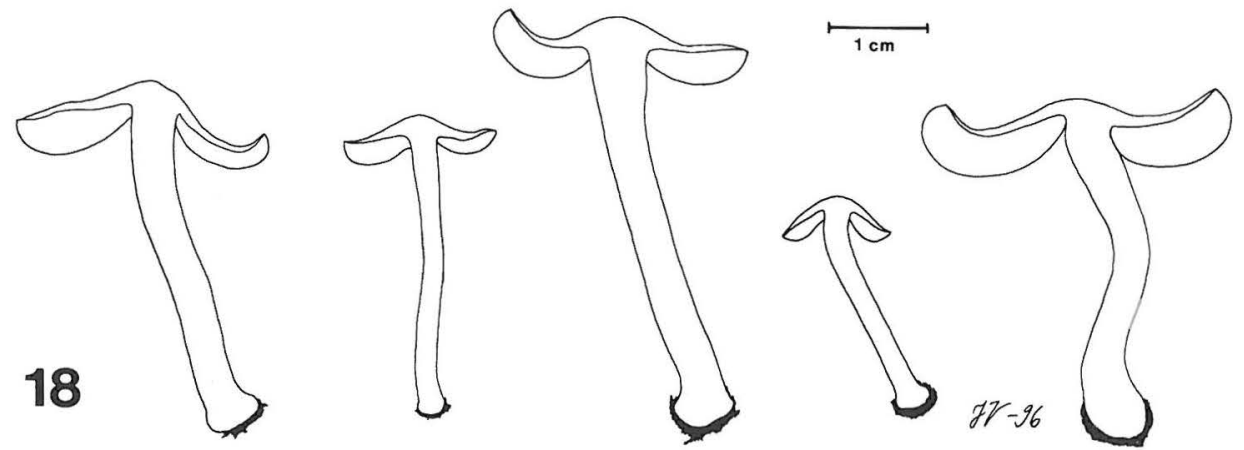

Fig. 18. Fruit bodies of Inocybe decemgibbosa (from Vauras 8115F), 1. 

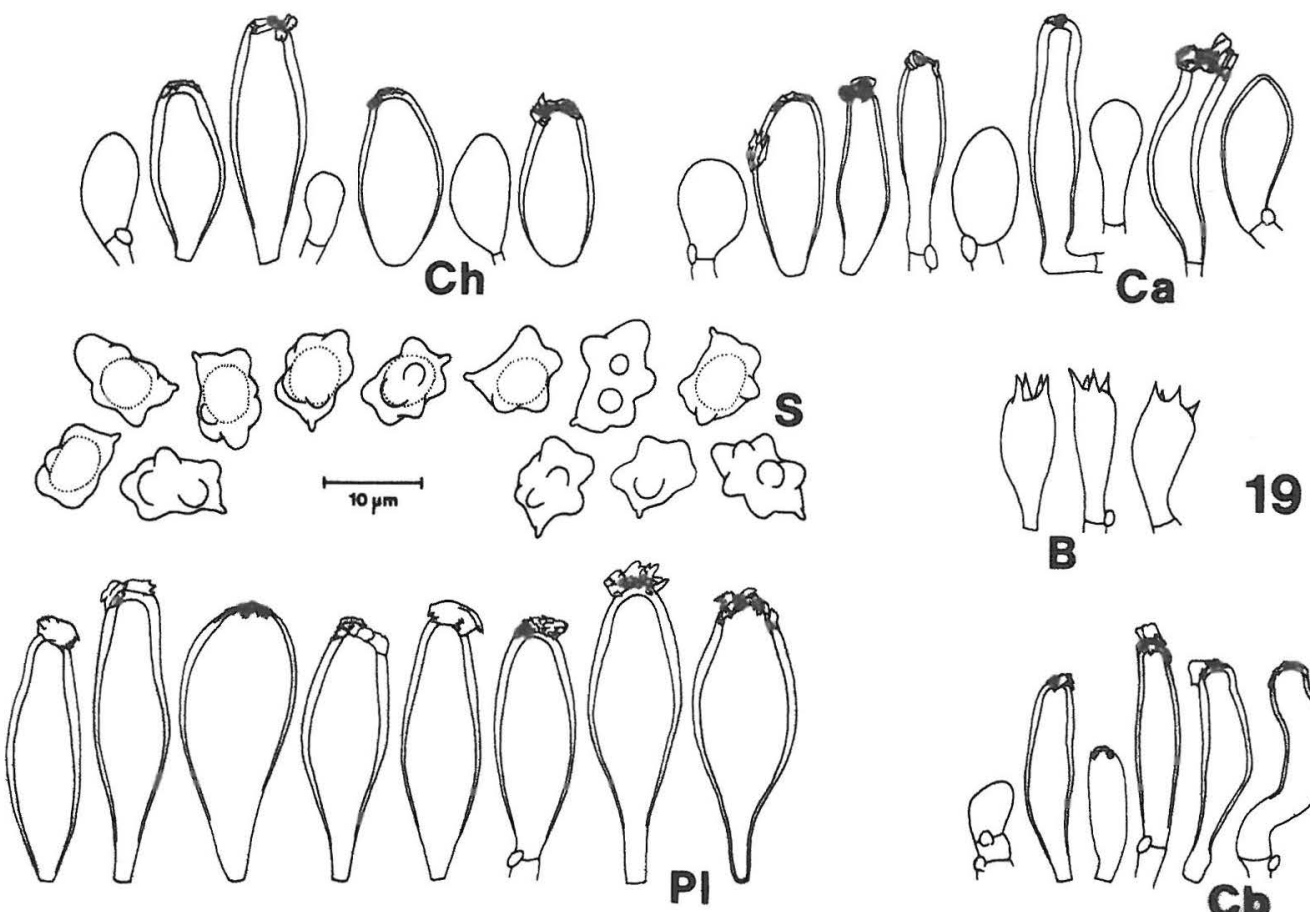

19

B
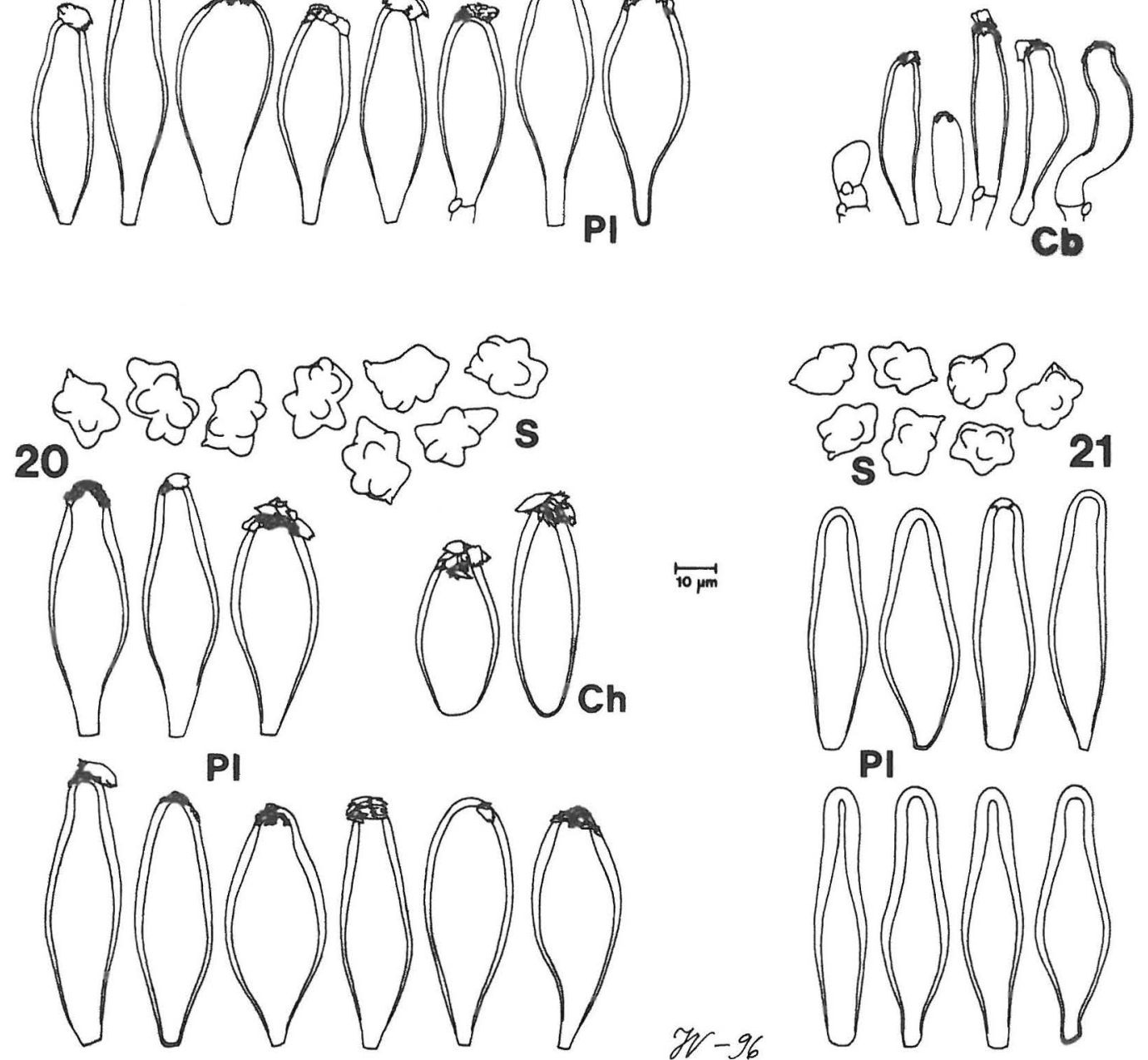

Figs. 19-21. Microscopical characters of Inocybe decemgibbosa and I. glabrodisca. - 19: I. decemgibbosa, from Vauras 8115F. - 20: I. decemgibbosa, from lectotype of I. oblectabilis f. decemgibbosa (G). - 21: I. glabrodisca (holotype, K). For symbols and scales see Figs. 3-5. 
Caulocystidia occurring down to base of stipe, smaller and narrower than pleurocystidia, up to $56 \mu \mathrm{m}$ long. Cauloparacystidia numerous, thin-walled, also present near base of stipe.

\section{Distribution, ecology and phenology}

Inocybe decemgibbosa is known from only one locality in Finland: close to a limestone processing plant in the municipality of Lohja, where it was twice found growing on a lawn in an established park, near a Tilia alley (Fig. 21). The distance to the nearest other trees (i.e. Betula pendula) is ca. $50 \mathrm{~m}$. I. decemgibbosa was found as an abundant group of 24 fruit bodies. The locality is at the northern limit of the hemiboreal zone.

Fungi sharing the growing site with $I$. decemgibbosa include I. adaequata (Britzelm.) Sacc. (reported here for the first time from Finland), $I$. dulcamara (Pers.) P. Kumm., I. erubescens A. Blytt, I. glabripes Ricken, I. langei R. Heim, I. perlata (Cooke) Sacc. and Agrocybe semiorbicularis (Bull. ex St. Amans) Fayod. The soil is calcareous ( $\mathrm{pH} 7.3$ ) due to a long-term emission of calcium from the limestone processing plant. The diversity of Inocybe species in the vicinity of the plant may be the richest in Finland.

I. decemgibbosa is a rare species. The Finnish locality is the only one known in Fennoscandia. $I$. oblectabilis f. decemgibbosa was first described from France (Kühner 1933), and later it was recorded as I. glabrodisca from Germany (Stangl \& Schwöbel 1985, Stangl 1989), France (MoënneLoccoz et al. 1990) and the Netherlands (Kuyper 1995). The species is not confined to calcareous soils, and it evidently grows only with deciduous trees, e.g. Quercus (Stangl \& Schwöbel 1985, Kuyper 1995) and Populus (Stangl 1989).

I. decemgibbosa seems to be a species fruiting early in the season. In Finland it was collected in late June and in mid-August. In Germany the fruiting period seems to be fairly similar, with a maximum in July (Stangl \& Schwöbel 1985, Stangl 1989). In France it has been found in midJune (Moënne-Loccoz et al. 1990) and in August (Kühner 1933).

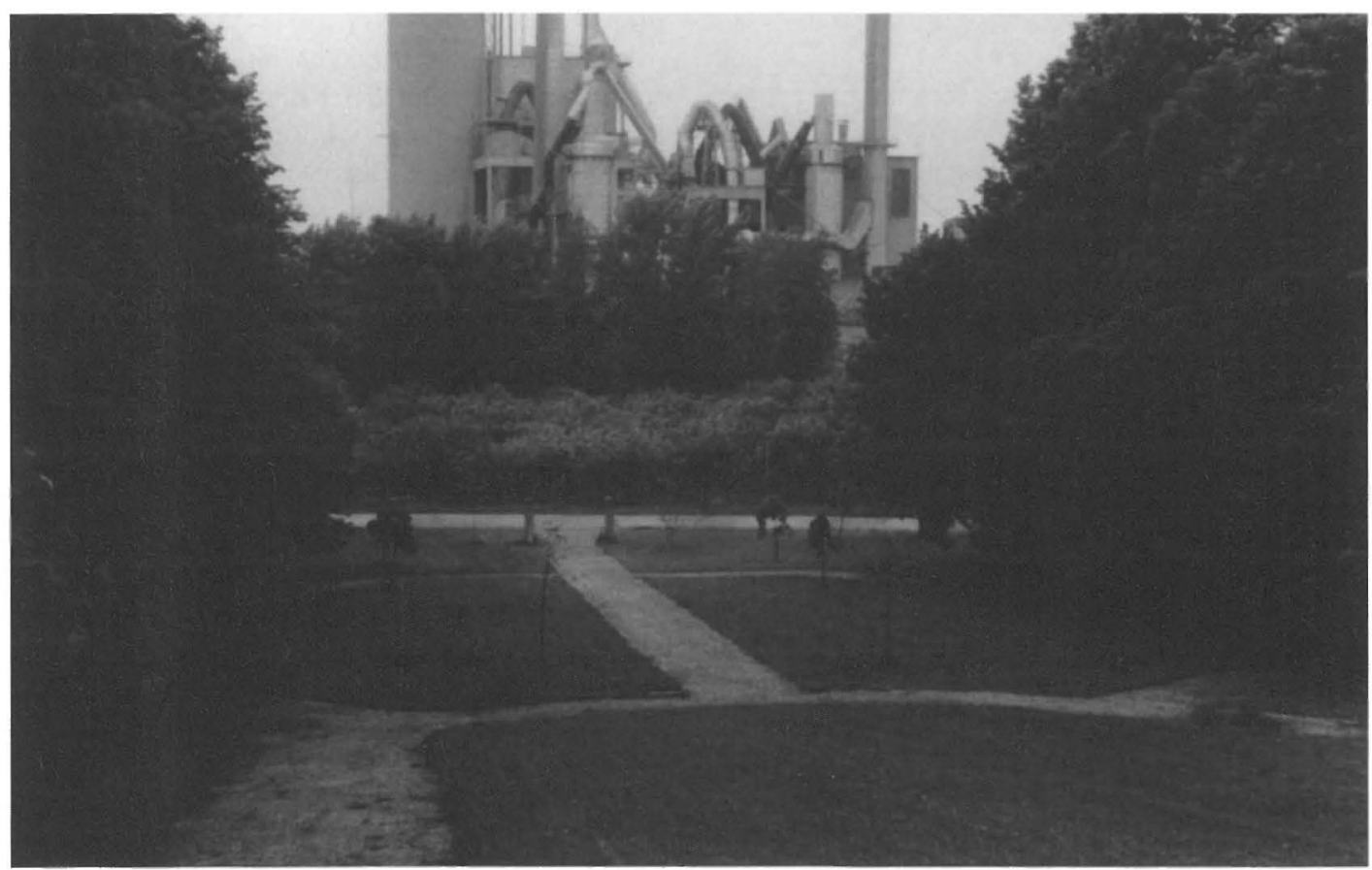

Fig. 22. The growing site of Inocybe decemgibbosa in Finland is in an established park close to a limestone processing plant. The species was found growing on lawn between two Tilia alleys. Varsinais-Suomi, Lohja, Kirkonkylä, photographed 30.VI.1994. 


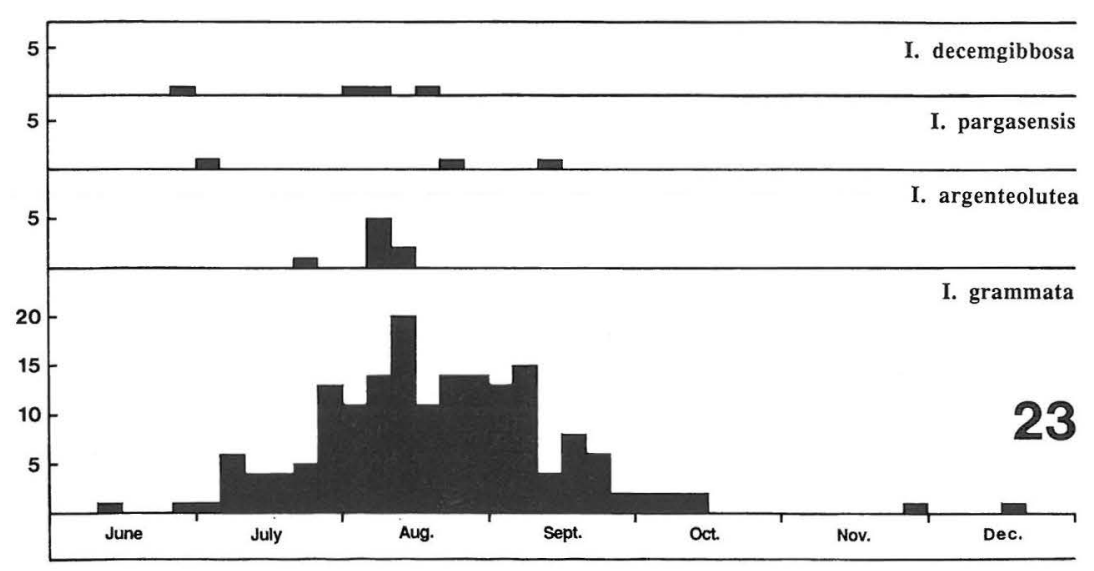

Fig. 23. Fruiting periods of Inocybe grammata, I. argenteolutea, I. pargasensis and $I$. decemgibbosa according to the specimens examined, divided into pentads. y axis: number of specimens collected in each pentad.

\section{Specimens examined}

Finland. Varsinais-Suomi: Lohja, Kirkonkylä, 1993 Vauras $8115 \mathrm{~F} *$ (TUR, TURA), 1994 Vauras $9055 *$ (TURA). France. Seine et Marne: Ozoir-la-Ferriére, 1929 Kühner "C.ct.gr." * (lectotype, G), 1930? Kühner "t.foss. B" * (G), 1932 Kühner "S-OZ 32" * (G), "S-OZ 32 forme $B$ " (G).

\section{Discussion}

Stangl \& Schwöbel (1985) state that Inocybe glabrodisca is identical with $I$. oblectabilis f. decemgibbosa, but when writing their paper the authors did not have the opportunity to study the type of $I$. glabrodisca. The synonymy was clearly based on Orton's (1960) description of $I$. glabrodisca and particularly on his statement "one of the smooth-capped oblectabilis group". This synonymy has been accepted by MoënneLoccoz et al. (1990), Esteve-Raventos \& Ortega (1995) and Kuyper (1995). I. glabrodisca was also taken as a member of the section Marginatae in the keys of Pegler \& Young (1972), Stangl \& Veselský (1980) and Stangl \& Enderle (1983).

In studying my collections filed as "I. glabrodisca" from Finland I found them to fit fairly well to the description of the form decemgibbo$s a$ by Kühner (1933), and with the descriptions of I. glabrodisca by Stangl \& Schwöbel (1985), Stangl (1989) and Moënne-Loccoz et al. (1990). However, Orton (1960) gives some characters of I. glabrodisca which are problematic, such as stipe structure, being pruinose at apex only, smaller spores "7.5-10 × 5-6.5 $\mu$ ", and further the form of pleurocystidia (Fig. 423) is somewhat deviating. Also Pegler \& Young (1972) measured rather small spores from the holotype of I. glabrodisca, being 7-8-9 $(-10) \times 4.5-5.3-6$ $\mu \mathrm{m}$.

All material of I. oblectabilis f. decemgibbo$s a$ in the herbarium R. Kühner $(\mathrm{G})$ consists of small pieces of pilei, without any fragments of stipes. My study of the lectotype gave the following measurements: spores 9.5-9.9-10.5 $(-11) \times(6.5-) 7-7.3-8 \mu \mathrm{m}, \mathrm{Q}=(1.2-) 1.3-1.35-$ $1.45(-1.5)(\mathrm{n}=20)$; pleurocystidia 55-62-72 $\times$ 18-21-26 $\mu \mathrm{m}(\mathrm{n}=15)$, crystals abundant, wall up to $3.5 \mu \mathrm{m}$ thick; cheilocystidia mostly shorter than pleurocystidia (Fig. 20). According to the original notes of R. Kühner (G), he first took this taxon as a new species, "Clypeus castaneogriseus n. sp.".

During my study of the holotype of I. glabrodisca, "England, Malham, Tarn House Plantation East, in Polytrichum under mixed trees, 1.IX.1958 Orton $1576(\mathrm{~K})$ "', I concluded that this taxon is not conspecific with $I$. decemgibbo$s a$. The spores are smaller than those of $I$. decemgibbosa, measuring 7- $\underline{8.3}-9.5 \times 5.5-\underline{6.2}-7$ $\mu \mathrm{m}, \mathrm{Q}=1.15-1.34-1.5(\mathrm{n}=30)$. As already drawn by Orton (1960: Fig. 423), the pleurocystidia are ventricose and with fairly long necks. Further, they are on average somewhat narrower $(51-\underline{60}-73 \times 12-\underline{15}-19 \mu \mathrm{m} ; \mathrm{n}=20)$ 
than in $I$. decemgibbosa, with a wall up to $3 \mu \mathrm{m}$ thick. The pleurocystidia are only rarely crystalliferous (Fig. 21). I could not find any caulocystidia. The type, probably originally consisting of two fruit bodies, has disintegrated rather badly. In my opinion I. glabrodisca should be taken as a member of the section Cortinatae Kühner \& Boursier. This can be supported by Orton's description "Stem... white pruinose at apex only, remainder white silky floccose or loosely scattered fibrillose".

I. decemgibbosa is a medium-sized species, characterized by red-brown, smooth pileus, pale red-brown, totally white-pruinose stipe and by a rather indistinct smell. I. oblectabilis and $I$. grammata have more peculiar, stronger smells. I. oblectabilis is more robust and has larger spores with more obscure nodules. I. grammata has paler pileus with grey-white velipellis and reddish to yellowish colours, reddish stipe and spores with more obscure nodules. I. mixtilioides Kuyper nom. prov. has more fibrillose pileus, stipe with brown-yellow tints, pleurocystidia with thicker walls and often rounded base, and it grows on fine sandy soils. I. asterospora Quél. has rimose pileus, very prominent white bulb at base of stipe, and stellate spores.

I. glabrodisca was reported from Estonia, Tallinn, by Shtshukin (1992), but the collection (TAA 141703) turned out to be I. grammata. The specimen recorded from Spain as I. glabrodisca (Esteve-Raventos \& Ortega 1995) is not conspecific with either I. decemgibbosa or $I$. glabrodisca. Part of this collection is deposited in TURA.

I. decemgibbosa should be included in the list of threatened fungi in Finland, as an endangered species.

Acknowledgements. My sincere thanks are due to the curators of herbaria which sent material on loan. Leif and Anita Stridvall (Trollhättan) kindly loaned me collections of Inocybe grammata from their private herbarium, Dr. F. Esteve-Raventos (Madrid) sent a duplicate of the Spanish collection filed as I. glabrodisca, and Prof. Joseph Ammirati (Seattle) sent duplicate specimens filed as $I$. albodisca. Prof. Teuvo Ahti (Helsinki) and Prof. Seppo Huhtinen (Helsinki) helped in nomenclatural and typification problems. I also wish to express my gratitude to them for their valuable comments on the manuscript. Grants from the Emil Aaltonen foundation, Suomen Kulttuurirahasto and Suomen Kulttuurirahaston Varsinais-Suomen osasto are gratefully acknowledged.

\section{References}

Alessio, C.L. 1980: Inocybe. Generalia et descriptiones. - Iconographia Mycologica 29, Suppl. 3. 367 pp. Comitato Onoranze Bresadoliane, Trento.

Anonymous 1992: Rote Liste der gefährdeten Grosspilze in Deutchland. - 144 pp. Deutsche Gesellschaft für Mykologie e.V., Naturschutzbund Deutschland e.V. Eching.

Arnolds, E. 1984: Standaardlijst van Nederlandse macrofungi. - Coolia 26, Suppl. 362 pp.

Azbukina, Z.N. \& Wasser, S.P. (eds.) 1990: Plantae non vasculares, fungi et bryopsida, orientis extremi sovietici. Fungi 1. Basidiomycetes. Russulaceae, Agaricaceae, Cortinariaceae, Paxillaceae, Gomphidiaceae, Strobilomycetaceae. - 405 pp. Nauka, Leningrad.

Cailleux, A. 1981: Code des couleurs des sols. Boubée.

Esteve-Raventos, F. \& Ortega, A. 1995: Checklist of the genus Inocybe in Andalusia (Peninsular Spain). Mycotaxon 54:245-261.

Favre, J. 1960: Catalogue descriptif des champignons supérieurs de la zone subalpine du Park National Suisse. - Ergeb. Wiss. Untersuch. Schweiz. Nationalparks 6:323-610.

Fries, E.M. 1838: Epicrisis systematis mycologici seu synopsis Hymenomycetum. - 610 pp. Uppsala.

Grund, D.W. \& Stuntz, D.E. 1980: Nova Scotian Inocybes. V. - Mycologia 72:670-688.

Gröger, F. 1986: Pilze aus der DDR. 14. Inocybe grammata Quél. - Höckersporiger Risspilz. - Mykol. Mitt.bl. 29:79-81.

Gulden, G. \& Lange, M. 1971: Studies in the Macromycete Flora of Jotunheimen, the Central Mountain Massif of South Norway. - Norw. J. Bot. 18:1-46.

Harmaja, H. 1969: Karstenella vernalis Harmaja, a new genus and species of Discomycetes from Finland. Karstenia 9:20-22.

Heim, R. 1931: Le genre Inocybe. - 429 pp. Encyclopédie Mycologique 1. Paul Lechevalier \& Fils, Paris.

Holmgren, P.K., Holmgren, N.H. \& Barnett, L.C. 1990: Index herbariorum 1. The herbaria of the world. 8th ed. - Regnum Vegetabile 120:1-693.

Huhtinen, S. \& Vauras, J. 1984: Sienilöytöjä Paraisilta. - Sienilehti 36:51-56.

Jacobsson, S. \& Vauras, J. 1990 ("1989"): Inocybe rivularis, a new boreal agaric. - Windahlia 18:15-24.

Krieglsteiner, G.J. 1989: Über neue, seltene, kritische Makromyzeten in der BR Deutschland (Mitteleuropa). XI. - Beiträge zur Kenntnis der Pilze Mitteleuropas 5:115-140.

Krieglsteiner, G.J. 1991: Verbreitungsatlas der Grosspilze Deutschlands (West). Band 1: Ständerpilze. Teil B: Blätterpilze. - 1016 pp. Verlag Eugen Ulmer, Stuttgart.

Kuyper, T.W. 1985: Studies in Inocybe - 1. Revision of the new taxa described by Velenovský. - Persoonia $12: 375-400$.

Kuyper, T.W. 1986: A revision of the genus Inocybe in Europe. 1. Subgenus Inosperma and the smoothspored species of the of subgenus Inocybe. - Persoonia, Suppl. 3:1-247. 
Kuyper, T.W. 1995: Inocybe (Fr.) Fr. - In: Arnolds, E., Kuyper, T.W. \& Noordeloos, M.E. (eds.), Overzicht van de paddestoelen in Nederland: 249-269 - Nederlandse Mycologische Vereniging, Wijster.

Kühner, R. 1933: Notes sur le genre Inocybe. - Bull. Soc. Mycol. France 49:81-121.

Küppers, H. 1981: DuMont's Farben-Atlas. 2nd ed. 163 pp. DuMont Buchverlag, Köln.

Lampolahti, J.T. 1991: Kimalaisorhon populaatiobiologia Paraisilla 1989. - Luonnon Tutkija 95:56-60.

Moënne-Loccoz, P., Poirier, J. \& Reumaux, P. 1990: Inocybe critiquables et critiqués. - Fungorum Rariorum Icones Coloratae 19:1-55.

Moser, M. 1992: On two interesting species of Inocybe from Sweden. - Persoonia 14:571-576.

Orton, P.D. 1960: New check list of British agarics and boleti. Part III. Notes on genera and species in the list. - Trans. Brit. Mycol.Soc. 43:159-439.

Pegler, D.N. \& Young, T.W.K. 1972: Basidiospore form in the British species of Inocybe. - Kew Bulletin 26:499-537, Plates 6-24.

Rebaudengo, E. 1980: Inocybe. Tabulae 1-100. - Iconographia Mycologica 29, Supp. 3. Comitato Onoranze Bresadoliane, Trento.

Ruotsalainen, J., Sarnari, M. \& Vauras, J. 1997: Russula fulvograminea, una nuova specie in Fennoscandia. Rivista Micol. 40:99-107.

Shtshukin, G. 1992: Fungi new for Estonia. - Folia Crypt. Estonica 30:10-11.

Stangl, J. 1979: Die eckigsporigen Risspilze (4). - Z. Mykol. 45:145-162.

Stangl, J. 1989: Die Gattung Inocybe in Bayern. - Hoppea 46:5-388.
Stangl, J. \& Enderle, M. 1983: Bestimmungsschlüssel für europäische eckigsporige Risspilze (Subgenus Inocybe). - Z. Mykol. 49:111-136.

Stangl, J. \& Schwöbel, H. 1985: Höckerig-sporige Risspilze aus dem Formenkreis der Inocybe oblectabilis (Britz. 1890) Sacc. 1895. - Int. J. Mycol. Lichenol. 2:53-74.

Stangl, J. \& Vauras, J. 1988: Über das Genus Inocybe in Finnland. Die neuen Arten I. mytiliodora and I. urceolicystis. - Karstenia 27:15-21

Stangl, J. \& Veselský, J. 1980: Analytische Bestimmungstabelle der europäischen höckerig-eckigsporigen Risspilze. Beiträge zur seltenerer Inocyben. Nr. 17. - Ceská Mykol. 34:45-53.

Stridvall, L., Stridvall, A. \& Jacobsson, S. 1989: Släktet Inocybe i Sverige. En preliminär översikt. - Jordstjärnan 10(2):29-76.

Stuntz, D.E. 1947: Studies in the genus Inocybe. I. New and noteworthyspecies from Washington. - Mycologia 39: 21-55.

Vauras, J. 1989: Kaksi Suomessa harvinaista risakasta, päärynärisakas ja imelärisakas. - Sienilehti 41:2430.

Vauras, J. 1991: Suomen kalkkialueiden sienistä. Luonnon Tutkija 95:64-67.

Vauras, J. 1994: Inocybe diabolica, a new boreal agaric from subarctic regions. - Mycologia Helvetica 6(2):121-128.

Vauras, J. 1995 ("1994"): Finnish records on the genus Inocybe. The new species I. hirculus. - Aquilo, Ser. Botanica 33:155-160.

Vauras, J. \& Huhtinen, S. 1986: Finnish records on the genus Inocybe. Ecology and distribution of four calciphilous species. - Karstenia 26:65-72.

Received on 30 July 1996 